Mariana Trivilin Mendes

\title{
Aminopeptidase básica e Leucotrieno-A4- hidrolase em Ratos Sensíveis e Insensíveis à Indução de Artrite por Colágeno Tipo II
}

Basic aminopeptidase and Leukotriene-A4-hydrolase of Rats Sensitive and Insensitive to Induction of Arthritis by Type-II Collagen

Versão Corrigida da Dissertação apresentada ao Instituto de Biociências da Universidade de São Paulo, para a obtenção de Título de Mestre em Ciências, na Área de Fisiologia Geral. Versão original encontra-se disponível no Instituto de Biociências da Universidade de São Paulo.

Orientador: Prof. Dr. Paulo Flávio Silveira

São Paulo 
Mariana Trivilin Mendes

\section{Aminopeptidase básica e Leucotrieno-A4- hidrolase em Ratos Sensíveis e Insensíveis à Indução de Artrite por Colágeno Tipo II}

Basic aminopeptidase and Leukotriene-A4-hydrolase of Rats Sensitive and Insensitive to Induction of Arthritis by Type-II Collagen

Dissertação apresentada ao Instituto de Biociências da Universidade de São Paulo, para a obtenção de Título de Mestre em Ciências, na Área de Fisiologia Geral.

Orientador: Prof. Dr. Paulo Flávio Silveira

São Paulo 


\section{Mendes, Mariana Trivilin}

Aminopeptidase básica (APB) e Leucotrieno-A4hidrolase (LTA4H) em Ratos Sensíveis e Insensíveis à Indução de Artrite por Colágeno Tipo II/ Mariana Trivilin Mendes ; orientador Paulo Flávio Silveira. --.

São Paulo, 2012.

$66 \mathrm{f}$.

Dissertação (Mestrado) -

Instituto de Biociências da Universidade de São Paulo. Departamento de Fisiologia.

1. Artrite reumatoide 2. Aminopeptidase básica

3. Leucotrieno-A4-hidrolase

I. Universidade de São Paulo. Instituto de Biociências. Departamento de Fisiologia Geral.

\section{Comissão Julgadora:}




\section{Dedicatória}

Agradeço primeiramente a Deus, que me colocou ao encontro de pessoas tão especiais neste mundo e sempre esteve ao meu lado.

À minha mãe, Linéia Ruiz Trivilin, que me ensinou o que é caráter, sempre me incentivou a estudar e esteve junto comigo em cada derrota, comemoração, lágrimas e sorrisos nessa jornada chamada vida.

Ao meu pai, José Mendes Filho, pelo apoio mesmo sem entender muito bem o que faço, pelo abraço amoroso todas as vezes que o vejo, por sempre me lembrar de Deus e pelos conselhos sempre certos.

Ao amor da minha vida Denis Pupo, que não me deixa desistir, aguenta meu mau humor, me faz esquecer as preocupações, é meu companheiro e me lembra sempre que todo o esforço vale a pena por um futuro melhor ao seu lado, por nós.

À minha melhor amiga, Camilla de Cássia Sovenhi, por uma amizade maravilhosa de nove anos, por entender minhas ausências, pela companhia inestimável até para ficar sem fazer nada, pelas conversas, risadas, trapalhadas, pelo ombro pra chorar e força sem tamanho. A todos da minha família, irmãs (Anna e Marília), padrasto (Pedro Kobler), tios (Amilton, Luiz), tias (Ligia, Livânia, Rosana), avós (Ana e Agripina), avô (Leonildo) e primos por toda experiência que me é doada, por todo carinho que me é dado e por me apoiarem sempre.

Às minhas amigas: Nathalia Fávero, Kelly de Albuquerque, Lorraine Istefane, Natassja Foizer, Aline Blasques, Jéssica Camila Rodrigues, Carmen Capell por mesmo sem entender meu trabalho ou fazendo a mesma coisa que eu, concordando ou não, me fazerem pensar que o que faço é importante, por me mostrarem o valor da amizade, das risadas fora de hora e dos abraços apertados quando se é preciso. A todas as pessoas que fizeram ou que fazem parte da minha vida e que de alguma maneira me ajudaram a ser quem sou e estar onde estou. 


\section{Epígrafe}

"Sem sonhos, a vida não tem brilho.

Sem metas, os sonhos não têm alicerces.

Sem prioridades, os sonhos não se tornam reais.

Sonhe, trace metas, estabeleça prioridades e corra riscos para executar seus sonhos. Melhor é errar por tentar do que errar por omitir!" 


\section{Agradecimentos}

Ao meu orientador Prof. Dr. Paulo Flávio Silveira, pela oportunidade e por sua inegável competência com que estabeleceu os caminhos e diretrizes desta pesquisa, por confiar no meu trabalho e por me deixar fazer parte de sua equipe tão maravilhosa.

Aos meus colegas de laboratório, Rafaela Fadoni Alponti Vendrame e Rodrigo Frezzatti pela companhia diária, pelas risadas, brincadeiras e também pela ajuda quando necessário, por sempre responderem minhas dúvidas e pela amizade que me é especial.

Aos colegas da Farmacologia II: Marlos Cortez, Ana Eduarda Zulim Carvalho, Marina Nogueira, Lívia Rocha e Márcio Matsubara por tornarem o trabalho agradável, pelos momentos de riso e pela constante ajuda.

Ao Eduardo Frare pelo grande auxílio na montagem dos meus slides, ajuda experimental inestimável e principalmente pela amizade.

Ao Leonardo Zambotti Villela, pela paciência e atenção com que me auxiliou durante meu trabalho.

A todos da equipe e colegas de trabalho do Instituto Butantan.

Agradeço à Joana Darc Carvalho Vieira e Roseli Silva Santos, secretárias, respectivamente, do Laboratório de Farmacologia do Instituto Butantan e do Departamento de Fisiologia da Universidade de São Paulo, pela dedicação e auxílio.

À Coordenação de Aperfeiçoamento de Pessoal de Nível Superior (CAPES) pela bolsa concedida.

À Fundação de Amparo à Pesquisa do Estado de São Paulo (FAPESP), pelo auxílio financeiro que tornou possível o desenvolvimento deste trabalho.

Ao Programa de pós-graduação em Fisiologia Geral no Instituto de Biociências da Universidade de São Paulo. 


\section{LISTA DE ABREVIATURAS}

\begin{tabular}{|c|c|}
\hline $5-\mathrm{LO}$ & 5-lipoxigenase \\
\hline AACII & anticorpo anti-colágeno tipo II \\
\hline Ang & angiotensina \\
\hline APB & aminopeptidase básica \\
\hline AR & artrite reumatoide \\
\hline ArgNA & L-arginina $\beta$-naftilamida \\
\hline BSA & albumina sérica bovina \\
\hline CIA & modelo de indução da artrite por colágeno tipo II \\
\hline COX & cicloxigenase \\
\hline CII & colágeno tipo II \\
\hline cPLA2 & fosfolipase A2 citosólica \\
\hline DEPC & dietilpirocarbonato \\
\hline DMSO & dimetil-sulfóxido \\
\hline DPPIV & dipeptidil peptidase IV \\
\hline EDTA & ácido etilenodiamino tetra-acético \\
\hline EIA & ensaio imunoenzimático \\
\hline FM & fração de membrana solubilizada \\
\hline FS & fração solúvel \\
\hline HPLC & cromatografia líquida de alta eficiência \\
\hline id & via intradérmica \\
\hline Inc & amostra incubada com LT-A4 \\
\hline ip & via intraperitoneal \\
\hline LDH & desidrogenase láctica \\
\hline LT & leucotrieno \\
\hline LT-A4-H & leucotrieno-A4-hidrolase \\
\hline $\mathrm{MHC}$ & moléculas do complexo principal de histocompatibilidade \\
\hline NADH & $\beta$-nicotinamida adenina di-nucleotídeo, forma reduzida \\
\hline PBMCs & células mononucleares do sangue periférico \\
\hline PBS & tampão fosfato \\
\hline PGP & Pro-Gly-Pro \\
\hline qPCR & reação quantitativa em tempo real em cadeia da polimerase \\
\hline RT & real time \\
\hline s-inc & amostra sem incubação com LT-A4 \\
\hline SY & líquido sinovial \\
\hline
\end{tabular}


TS

tecido sinovial

TNF- $\alpha$ fator de necrose tumoral tipo $\alpha$ 


\section{LISTA DE TABELAS}

Tabela 1 - Atividade APB no plasma, líquido sinovial (SY), frações solúvel (FS) e de membrana solubilizada (FM) do tecido sinovial (TS) e de células mononucleares do sangue periférico (PBMCs) de ratos controles, artritícos e resistentes

Tabela 2 - Níveis de LT-B4 (pg/mL) medidos por área dos picos do HPLC e por EIA direto das amostras de plasma, líquido sinovial (SY), frações solúvel (FS) e de membrana solubilizada (FM) do tecido sinovial (TS) e de células mononucleares do sangue periférico (PBMCs) de ratos controles, artríticos e resistentes, incubadas (inc) ou não (s-inc) com LT-A4------------------------24

Tabela 3 - Atividade LT-A4-H (pg de LT-B4 formado / $\mathrm{min} / \mathrm{mL}$ ) do plasma, líquido sinovial (SY) e frações solúvel (FS) e de membrana solubilizada (FM) do tecido sinovial (TS) e de células mononucleares do sangue periférico (PBMCs) de ratos controles, artríticos e resistentes------------26

Tabela 4 - Sentido das alterações nos níveis de LT-B4 e de atividades de APB e LT-A4-H em ratos artríticos e resistentes no modelo CIA, relativamente aos controles sadios- 


\section{LISTA DE ILUSTRAÇÕES}

Figura 1 - Análise bidimensional da atividade hidrolítica de LT-A4-H sobre substrato epóxido LTA4 e sobre substrato peptídico, conforme proposto por DE OLIVEIRA et al (2011)-------------------8

Figura 2 - Expressão gênica relativa da aminopeptidase básica (APB) (EC 3.4.11.6) e da leucotrieno-A4-hidrolase (LT-A4-H) (EC 3.3.2.6) no tecido sinovial de animais controles sadios-19

Figura 3 - Corrida típica em HPLC do padrão LT-B4 e de material biológico------------------------21

Figura 4 - Regressão linear entre níveis de LT-B4 e áreas dos picos correspondentes no HPLC---21

Figura 5 - Regressão linear entre níveis de LT-B4 e valores de absorbância em $\lambda=412 \mathrm{~nm}$ obtidos no EIA para as amostras analisadas--------------------------------------------------------------22

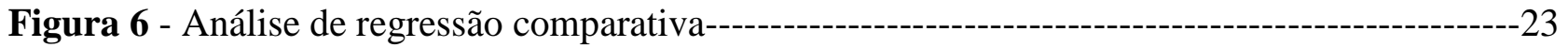

Figura 7 - Regressão linear entre os níveis de LT-B4 em todas as amostras sob estudo, medidos por área do pico do HPLC e por EIA-----------

Figura 8 - Esquema ilustrativo dos resultados obtidos na presente dissertação, mostrando alterações nos níveis do conteúdo de LT-B4 e de atividades LT-A4-H e APB em ratos artríticos e resistentes à

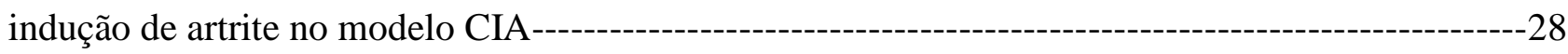




\section{Índice}

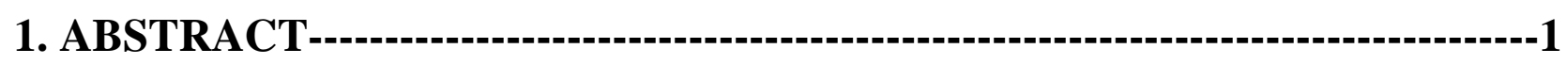

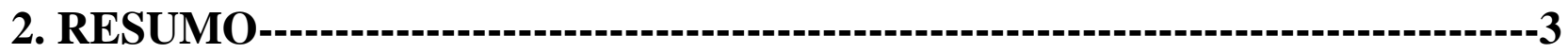

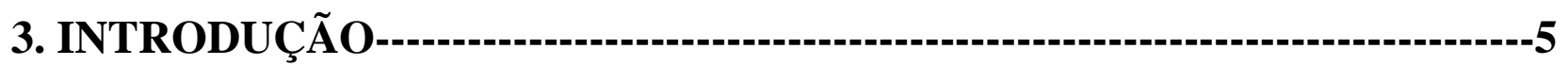

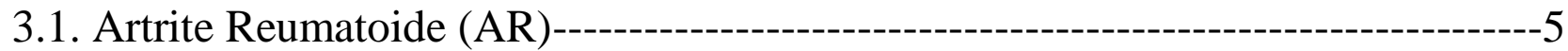

3.2. Artrite induzida em ratos por colágeno tipo II----------------------

3.3. Atividades aminopeptidásica e epóxido-hidrolase na AR --------------------------6

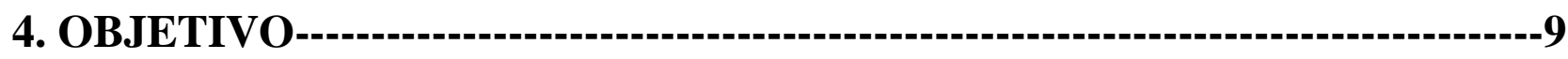

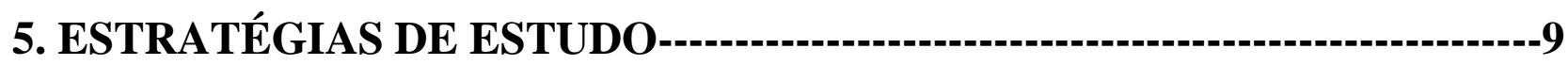

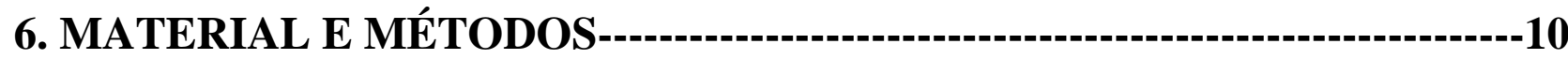

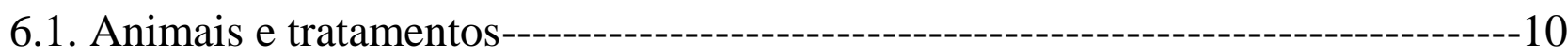

6.2. Avaliação do edema das patas ------11

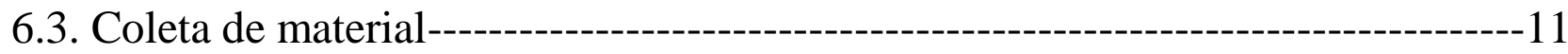

6.4. Obtenção de Células Mononucleares do Sangue Periférico (PBMCs)----------12

6.4.1. Contagem de PBMCs-------------12

6.4.2. Viabilidade de PBMCs---12

6.5. Obtenção da FS e da FM do tecido sinovial e de PBMCs---------------------12

6.6. Medida de TNF- $\alpha$ e AACII--------13

6.7. Proteína total------------------------------------------------------------------------13

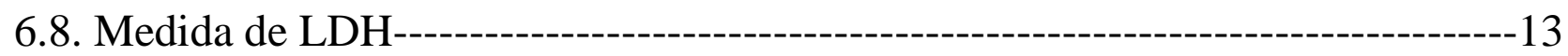

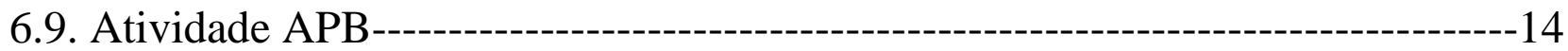

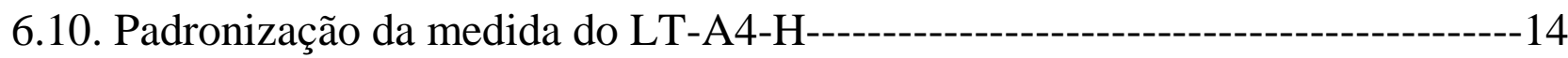

6.10.1. EIA--

6.10.2. HPLC--

6.10.3. Teor de LT-B4-16

6.10.4. Atividade LT-A4-H--

6.11. Expressão gênica da APB e da LT-A4-H---------------------------------------16

6.11.1. Extração do RNA---16

6.11.2. Transcrição Reversa (construção da fita de DNA complementar - cDNA)--------17

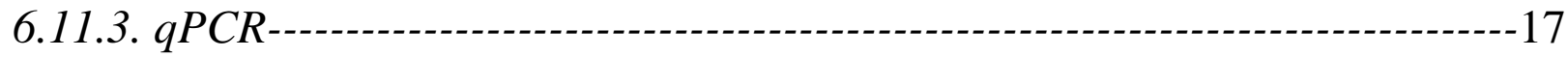

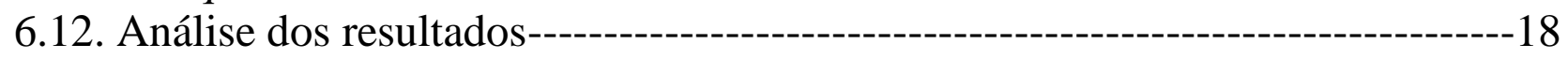

7. RESULTADOS---:--.--18

7.1. Classificação dos animais pela suscetibilidade à indução de artrite----------------18

7.2. Eficiência do fracionamento do TS e de PBMCs ---------------------19

7.3. Expressão gênica de APB (EC 3.4.11.6) e de LT-A4-H (EC 3.3.2.6)-----------19

7.4. Atividade APB------------------------------ 19

7.5. Teor de LT-B4 e atividade LT-A4-H-----------------------------------20 


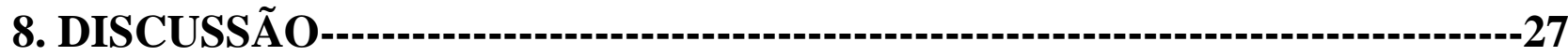

8.1. Avaliação da indução da artrite no modelo CIA---------------------29

8.2. Avaliação do fracionamento do tecido sinovial e de PBMCs------------------30

8.3. Atividade APB----------------------- 30

8.4. Níveis de LT-B4 e atividade de LT-A4-H--------------------------------31

8.4.1. Por que comparar as medidas de LT-B4 nas metodologias HPLC e EIA-31

8.4.2. Níveis de LT-B4 medidos pela área do pico obtido em HPLC----------32

8.4.3. Niveis de LT-B4 medidos por EIA diretamente em material bruto----------32

8.4.4. Comparação dos níveis de LT-B4 obtidos por EIA do pico de HPLC versus EIA das amostras brutas---------32

8.4.5. Significado da medida de LT-B4 em amostras sem incubar e incubadas com LT-A4---------- 32

8.5. Expressão gênica de APB (EC 3.4.11.6) e de LT-A4-H (EC 3.3.2.6)------------34 8.6. Correlações entre os níveis de LT-B4 e as atividades LT-A4-H e APB e seu possível significado na funcionalidade das proteínas responsáveis por estas atividades e na resistência e no desenvolvimento de artrite no modelo CIA-----------34

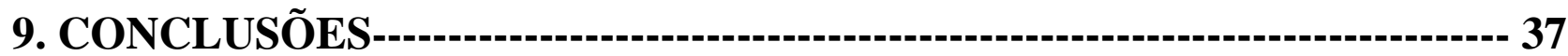

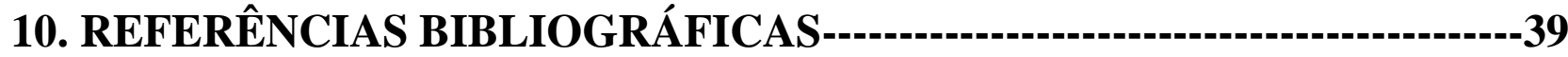

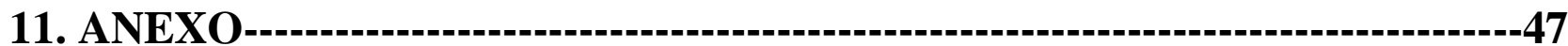




\section{ABSTRACT}

Whether L-arginyl-B-naphthylamide (ArgNA) and leukotriene (LT)-A4 hydrolyses by LT-A4 hydrolase (LT-A4-H) (EC 3.3.2.6) and basic aminopeptidase (APB) (EC 3.4.11.6) influence the development of collagen-induced arthritis (CIA) is presently uncertain. The objective of this study was to investigate the interrelationship among LT-A4-H, APB and LT-B4 in CIA rats. High-performance liquid chromatography (HPLC), enzyme immunoassay (EIA), spectrofluorometry and quantitative real time polymerase chain reaction (qPCR) were used as methodologies. The existence of genes for EC 3.3.2.6 and EC 3.4.11.6 proteins was confirmed in the synovial tissue of healthy control rats. ArgNA hydrolysis was higher in soluble fraction of synovial tissue in rats submitted to CIA that developed the disease (CIAarthritic) than in those that did not develop the disease (CIA-resistant) or healthy control. Synovial fluid and blood plasma had lower ArgNA hydrolysis in CIA-resistant than in CIAarthritic or control. In the peripheral blood mononuclear cells ArgNA hydrolysis was higher in soluble fraction of control and in membrane-bound fraction of CIA-resistant than in CIAarthritic. ArgNA hydrolysis differed between CIA-arthritic and CIA-resistant in soluble and membrane-bound fractions of synovial tissue, membrane-bound fraction of mononuclear cells, synovial fluid and blood plasma. Compared with healthy control, LT-A4 hydrolysis was higher in synovial fluid and in soluble fraction from mononuclear cells of CIA-arthritic and CIA-resistant. LT-A4 hydrolysis was also higher in membrane-bound fraction from synovial tissue of CIA-resistant, while it was lower in membrane-bound fraction of mononuclear cells of CIA-arthritic and CIA-resistant than in control. In all these locations hydrolysis of ArgNA remained unchanged or it was inversely related with LT-A4 hydrolysis, comparatively to healthy control. Also compared with control, changes on the levels of LT-A4 hydrolysis and LT-B4 content had the same sense between CIA-resistant and CIA-arthritic in all compartments, with the exception of membrane-bound fraction of synovial tissue and soluble fraction of mononuclear cells. However, quantitative comparison between CIA-arthritic and CIA-resistant showed different levels of LT-A4 hydrolysis in synovial fluid, membranebound fraction of synovial tissue and soluble fraction of mononuclear cells, together with different levels of LT-B4 content in membrane-bound fraction of synovial tissue and soluble fraction of mononuclear cells. On the other hand, a same-sense relationship was found between altered levels of LT-A4 hydrolysis and LT-B4 content only in synovial fluid and membrane-bound fraction of mononuclear cells of CIA-arthritic and CIA-resistant and in membrane-bound fraction of synovial tissue of CIA-resistant, comparatively to healthy control. In conclusion, the levels of LT-A4-H activity and LT-B4 content of CIA-arthritic and 
CIA-resistant in relation to control permit the distinction of these two statuses from healthy status. Although changes on LT-A4-H activity and LT-B4 content of CIA-arthritic and CIAresistant in relation to control have the same sense, quantitatively they are distinctive between these two statuses. The measurements of LT-A4-H activity and LT-B4 content have potential diagnostic use and their altered levels might be implications on the development or resistance to arthritis. APB activity is a potential marker of CIA-arthritis and resistance to CIA. The levels of LT-B4 are not controlled only by LT-A4-H. LT-A4-H and APB are related in a compartment-dependent manner acting as independent enzymes with differential modulation of their specificity, efficiency and/or catalytic affinity on the aminoacyl and epoxy substrates, or as bifunctional or interdependent enzymes which activities are inversely related due to the concurrent inhibition of one of these.

keywords: autoimmunity, arthritis, animal model, bifunctional enzymes, aminopeptidase, leukotriene. 


\section{RESUMO}

Atualmente, ainda é incerto se a hidrólise de L-arginil- $\beta$-naftilamida (ArgNA) e do leucotrieno (LT)-A4 pela LT-A4-hidrolase (LT-A4-H) (EC 3.3.2.6) e pela aminopeptidase básica (APB) (EC 3.4.11.6) tem influência no desenvolvimento da artrite induzida por colágeno (CIA). O objetivo deste estudo foi investigar a inter-relação entre LT-A4-H, APB e LT-B4 em ratos submetidos à CIA. Cromatografia líquida de alta eficiência (HPLC), ensaio imunoenzimático (EIA), espectrofluorimetria e reação quantitativa em tempo real em cadeia da polimerase (qPCR) foram usados como metodologias. A existência dos genes para as proteínas EC 3.3.2.6 e EC 3.4.11.6 foi confirmada no tecido sinovial de ratos controles sadios. A hidrólise de ArgNA foi maior na fração solúvel do tecido sinovial dos animais submetidos à CIA que desenvolveram a doença (artríticos-CIA) que naqueles que não desenvolveram a doença (resistentes-CIA) e nos controles sadios. No líquido sinovial e no plasma sanguíneo houve menor hidrólise de ArgNA nos resistentes-CIA que nos artríticos-CIA e controles. Nas células mononucleares do sangue periférico a hidrólise de ArgNA foi maior na fração solúvel dos controles e na fração de membrana dos resistentes que nos artríticos-CIA. A hidrólise de ArgNA diferiu entre artríticos-CIA e resistentes-CIA nas frações solúvel e de membrana do tecido sinovial, fração de membrana das células mononucleares, líquido sinovial e plasma. Em comparação com controles sadios, a hidrólise de LT-A4 foi maior no líquido sinovial e na fração solúvel de células mononucleares de artríticos-CIA e resistentes-CIA. A hidrólise de LT-A4 também foi maior na fração de membrana do tecido sinovial de resistentes-CIA, enquanto foi menor na fração de membrana de células mononucleares de artríticos-CIA e resistentes-CIA, comparativamente aos controles. Em todos estes compartimentos a hidrólise de ArgNA permaneceu inalterada ou relacionou-se inversamente com a hidrólise de LT-A4, comparativamente aos controles sadios. Também comparativamente aos controles, as alterações nos níveis de hidrólise de LT-A4 e do conteúdo de LT-B4 tiveram o mesmo sentido entre artríticos-CIA e resistentes-CIA em todos os compartimentos, com exceção da fração de membrana do tecido sinovial e da fração solúvel das células mononucleares. No entanto, a comparação quantitativa entre artríticos-CIA e resistentes-CIA mostrou níveis diferentes de hidrólise de LT-A4 no fluido sinovial, fração de membrana do tecido sinovial e fração solúvel de células mononucleares, juntamente com níveis diferentes do conteúdo de LT-B4 na fração de membrana do tecido sinovial e na fração solúvel das células mononucleares. Por outro lado, uma relação no mesmo sentido foi encontrada entre alterações nos níveis de hidrólise de LT-A4 e do teor de LT-B4 apenas no líquido sinovial e na fração de membrana de células mononucleares dos artríticos-CIA e resistentes-CIA e na fração de membrana do tecido 
sinovial dos resistentes-CIA, comparativamente aos controles sadios. Em conclusão, os níveis de atividade LT-A4-H e do teor de LT-B4 de artríticos-CIA e resistentes-CIA em relação aos controles permitem a distinção dessas duas condições da condição saudável. Apesar das alterações de atividade LT-A4-H e do teor de LT-B4 dos artríticos-CIA e resistentes-CIA em relação aos controles terem o mesmo sentido, elas são quantitativamente distintas entre essas duas condições. As medidas da atividade LT-A4-H e do teor de LT-B4 têm potencial para uso diagnóstico e as alterações em seus níveis devem ter implicação no desenvolvimento ou resistência à artrite. A atividade APB é potencial marcadora da artriteCIA e da resistência à CIA. Os níveis de LT-B4 não são controlados somente pela LT-A4-H. LT-A4-H e APB estão relacionadas de uma forma compartimento-dependente, atuando como enzimas independentes, com modulação diferencial das suas especificidades, eficiências e/ou afinidades catalíticas sobre os substratos epóxi e peptídico, ou como enzimas bifuncionais ou interdependentes, cujas atividades são inversamente relacionadas devido à inibição concorrente de uma destas atividades.

palavras-chave: autoimunidade, artrite, modelo animal, enzimas bifuncionais, aminopeptidase, leucotrieno. 


\section{INTRODUÇÃO}

\subsection{Artrite Reumatoide (AR)}

A AR é uma doença inflamatória crônica que acomete preferencialmente mulheres e é primordialmente caracterizada pela progressiva destruição da cartilagem e ossos articulares (MCINNES et al., 2011; DOAN \& MASSAROTTI, 2005; PANAYI, 2005; BRAND et al., 2003; NAKAMURA, 2000). Sua etiologia é desconhecida (DOAN \& MASSAROTTI, 2005) e os mecanismos para o seu estabelecimento ainda não são completamente compreendidos (ROSENZWEIG et al., 2009).

A AR é caracterizada por poliartrite periférica, simétrica, com erosões ósseas e da cartilagem, consequente deformidade e destruição das articulações (HOLMDAHL et al., 2001). Este processo está associado com a hiperplasia inflamatória da membrana sinovial, também conhecida como pannus (STUART et al., 1984), pela neovascularização, que ocorre depois da infiltração das células inflamatórias na membrana sinovial (PANAYI, 2005), e pela resposta imune contra os componentes da cartilagem, entre eles o colágeno tipo II (CII), o qual tem sido o mais usualmente relacionado com essa resposta (HOLMDAHL et al., 2001).

Estima-se que a predisposição genética relacionada aos genes do complexo principal de histocompatibilidade (MHC) teria uma contribuição de cerca de 50\% ou menos para o desenvolvimento da doença (STRIETHOLT et al., 2008). Assim, diversos fatores epigenéticos também estão envolvidos no desencadeamento da AR, como metilação do DNA, splicing alternativo, micro RNAs e modificações de histonas (STRIETHOLT et al., 2008). Além disso, fatores como infecções, fumo, gravidez, hormônios sexuais e outros podem levar à autoimunidade (KOBAYASHI et al., 2008).

Sabe-se que a AR ocorre em função de uma resposta imune contra componentes da cartilagem (BRAND et al., 2003; CREMER et al., 1998). Várias citocinas estão implicadas na AR, como o fator de necrose tumoral tipo (TNF)- $\alpha$, a interleucina (IL)-1 e IL-6. Destas, o TNF- $\alpha$ destaca-se como um mediador pró-inflamatório dominante e um importante alvo terapêutico (OKAMOTO et al., 2008), sendo encontrado em altas concentrações no soro e no líquido sinovial de pacientes com a doença (SCOTT et al., 2010; CAO et al., 2007; DOAN \& MASSAROTTI, 2005; PANAYI, 2005; WEYAND \& GORONZY, 1999). 


\subsection{Artrite induzida em ratos por colágeno tipo II (CIA)}

O CII é evidentemente o antígeno primário na CIA e é provável que também tenha importância destacada na AR, por se tratar de um dos componentes mais abundantes da cartilagem articular (NAKAMURA, 2000). Anticorpos anti-CII (AACII) são detectados no líquido sinovial (HIETALA et al., 2004; CREMER et al., 1998), enquanto células B estão presentes na membrana sinovial (CREMER et al., 1998). Além disso, a artrite induzida em ratos por CII (CIA) é um modelo experimental de autoimunidade (KIM et al., 2012; BRAND et al., 2003; MYERS et al., 1997; GRIFFITHS, 1988; STUART et al., 1988; TRENTHAN et $a l ., 1977)$ que gera uma poliartrite erosiva (BRAND et al., 2003; CREMER et al., 1998; STUART et al., 1988) e tem sido estudado intensivamente por causa de suas semelhanças com a AR (KIM et al., 2012; HIETALA et al., 2004; CREMER et al., 1998; MYERS et al., 1997; TRENTHAN et al., 1977). A transferência de AACII também é capaz de induzir a AR, já que esses anticorpos se ligam à cartilagem normal ativando o sistema complemento (HIETALA et al., 2004).

No modelo CIA os sintomas em ratos e camundongos têm início cerca de 21 dias após a injeção de CII na dose usualmente utilizada (TRENTHAM et al., 1977). De acordo com STUART et al (1988), a lesão inicial observável é a deposição de fibrina na membrana sinovial no $5^{\circ}$ dia após a imunização. No $12^{\circ}$ dia observa-se intensa deposição de fibrina e hiperplasia do tecido, e no $19^{\circ}$ dia começa a infiltração de células mononucleares e polimorfonucleares. A inflamação é tão rápida que a destruição da cartilagem e a erosão óssea ocorrem em poucos dias (STUART et al., 1988). As principais características comuns conhecidas entre esse modelo e a AR são sinovite, formação progressiva de pannus, erosão marginal do osso e destruição da cartilagem (KIM et al., 2012; MYERS et al., 1997; STUART et al., 1988).

\subsection{Atividades aminopeptidásica e epóxido-hidrolase na AR}

O papel de enzimas na etiologia de doenças inflamatórias tais como a AR e a osteoartrite tem sido foco de investigações há várias décadas (TU et al., 2008; XUE et al., 2007; LEE \& MURPHY, 2005). Duas metaloenzimas dependentes de zinco (PHAM et al., 2007; PENNING et al., 2002; FOULON et al., 1999; RAWLINGS et al., 1998) parecem exibir concomitantemente atividades hidrolíticas sobre L-arginil- $\beta$-naftilamida (ArgNA) e sobre o leucotrieno (LT)-A4. São elas a LT-A4-hidrolase (LT-A4-H) (EC 3.3.2.6) e a aminopeptidase 
básica (APB) (EC 3.4.11.6) (GRICE et al., 2008; LIANG et al., 2007; MANTLE et al., 1999; RAWLINGS et al., 1998; RUDBERG et al., 2002; FITZPATRICK et al., 1994).

A APB hidrolisa preferencialmente resíduos básicos (arginina e lisina) (HUI et al., 2006; PIESSE et al., 2004; FOULON et al., 1999; RAWLINGS et al., 1998) e é estruturalmente semelhante à LT-A4-H (33\% de identidade e 48\% de similaridade), também exibindo essa atividade (PENNING et al., 2002; FOULON et al., 1999; CADEL et al., 1997). Não está esclarecido se haveria interferência recíproca dos substratos peptídico e eicosanóide em cada uma das atividades catalíticas da APB. MANTLE et al (1999) sugerem que alterações nos LTs geram alterações na atividade da APB. Outras atividades aminopeptidásicas, especificamente a neutra e a dipeptidil peptidase IV (DPPIV) já foram relacionadas com a etiologia e desenvolvimento de alterações artríticas no modelo CIA (YAMASAKI et al., 2012). A potencial importância da atividade APB na AR estaria relacionada com sua participação no processamento de peptídeos (HWANGA \& HOOKA, 2008), provavelmente associada com a maturação pós-translacional na rede trans-Golgi, e em processos de regulação na membrana plasmática, o que inclui hidrólise extracelular de vários potenciais substratos peptídicos de relevância fisiológica, além da participação nas etapas finais de processamento de precursores de hormônios (PHAM et al., 2007). No presente momento, a relevância das duas funções catalíticas da APB continua a ser uma questão em aberto (PHAM et al., 2007; PIESSE, et al., 2002, FOULON et al., 1999), mas sua ação em ampla faixa de pH demonstra sua adaptabilidade a vários sub-compartimentos celulares e seu envolvimento em um amplo espectro de fenômenos fisiológicos (FOULON et al., 1999), no qual se inclui os processos inflamatórios (PHAM et al., 2007; FOULON et al., 1999).

A Figura 1 ilustra a possível relação da bifuncionalidade catalítica sobre substrato peptídico e substrato epóxido da EC 3.3.2.6, na qual se observa que quando o substrato LTA4 (ácido 5,6-óxido-7,9-trans-11,14-ciseicosatetraenóico) e um substrato peptídico são alinhados nas suas porções de ácido carboxílico, a adição de água ocorre provavelmente em pelo menos duas regiões diferentes da enzima e que, portanto, o local de hidrólise dos dois substratos ocorre em regiões diferentes da enzima. (ANDERSON et al., 2009). 


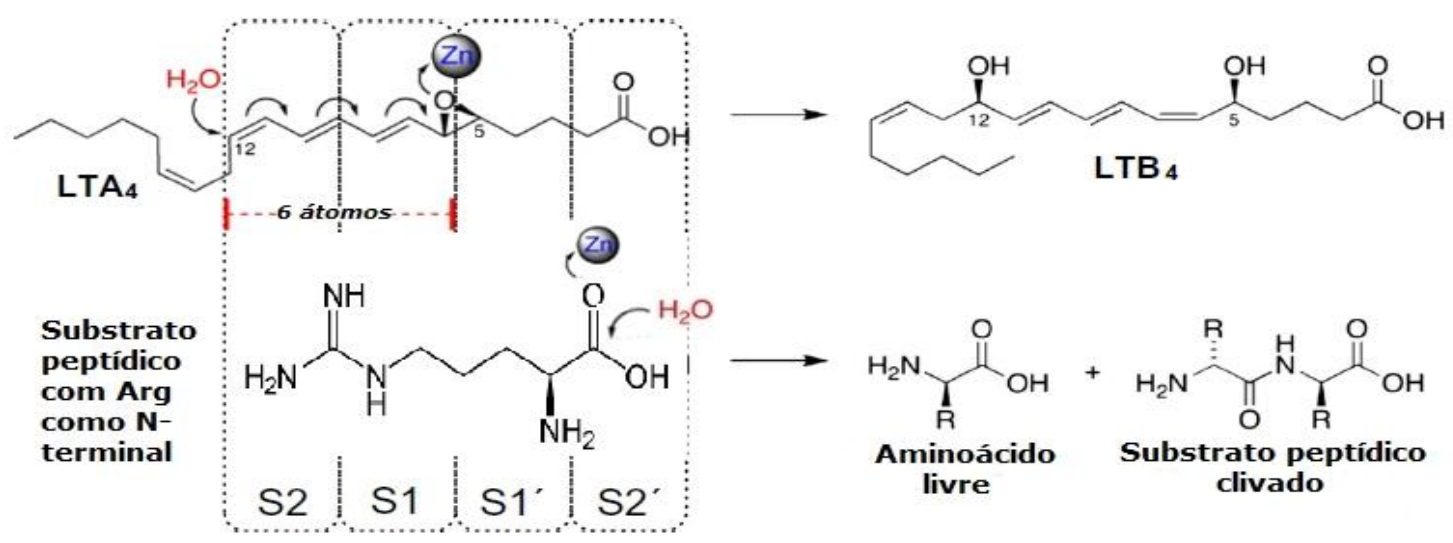

Figura 1. Análise bidimensional da atividade hidrolítica de LT-A4-H sobre substrato epóxido LT-A4 e sobre substrato peptídico, conforme proposto por DE OLIVEIRA et al (2011).

É reconhecido que LT-A4-H de humanos e roedores é uma enzima solúvel e monomérica (ZAITSU et al., 2000; RAWLINGS et al., 1998), mas há pelo menos um relato de atividade LT-A4-H ligada à membrana em hepatócitos (GUT et al., 1987). Além da atividade epóxido hidrolase sobre LT-A4, a LT-A4-H também parece exibir atividade sobre ArgNA, o substrato sintético preferencial da APB (GRICE et al., 2008). Ambas as atividades catalíticas da LTA4-H são inibidas por cátions divalentes e a atividade de aminopeptidase é estimulada por ânions monovalentes, incluindo cloreto (LIANG et al., 2007; RUDBERG et al., 2002; RAWLINGS et al., 1998;). A LT-A4-H parece sofrer inativação suicida (de ambas atividades: epóxido e aminopeptidásica) quando exposta ao seu substrato lipídico LT-A4 (RAWLINGS et al., 1998; FITZPATRICK et al., 1994).

Embora pareça óbvia a potencial importância da atividade LT-A4-H na AR, por sua ação decisiva na formação de LT-B4 (ácido 5[S],12[R]-dihidroxi-6,14-cis-8,10transeicosatetraenóico), ainda são raros os estudos abordando esta questão (ANDERSON et al., 2009). Por outro lado, é necessário avaliar a possível inter-relação das atividades catalíticas sobre ArgNA e LT-A4 na AR, pois isto ajudaria a identificar possíveis alterações na formação de LT-B4, a inferir o papel de substratos peptídicos suscetíveis e a revelar um possível padrão de bifuncionalidade catalítica alterado nesta doença. O envolvimento da LTA4-H com a AR, por meio da formação de LT-B4 é uma hipótese atraente, pois o LT-B4 é um potente mediador pró-inflamatório sintetizado por células imunes, como eosinófilos, neutrófilos e macrófagos, o qual estimula a produção de várias citocinas (PENNING et al., 2002), sendo reconhecidamente um fator quimiotático potente durante o início da inflamação (RYAN \& GODSON, 2010; HAEGGSTRÖM, 2000), além de promover degranulação, aumento da liberação de enzimas lisossômicas e produção de superóxidos por neutrófilos (FORD-HUTCHINSON, 1990; SAMUELSSON et al., 1987). Sabe-se que a via de síntese do 
LT-B4 tem três fatores cruciais. O primeiro relacionado com a formação de ácido araquidônico, onde as cicloxigenases (COX) oferecem uma alternativa para a 5-lipoxigenase (5-LO), enzima chave na síntese de LT-B4, gerar prostaglandinas. A 5-LO incorpora um grupo hidroperoxi ao carbono 5 do ácido araquidônico, formando o ácido 5hidroperoxieicosatetraenóico, que é precursor do LT-A4. O LT-A4 pode ser convertido em LT-B4 por hidrólise, ou em LT-C/D/E4 por conjugação com glutationa. Assim, outro ponto crucial relaciona-se com a LT-C4 sintase, a qual gera LT-C/D/E4. Um último fator correlaciona-se com a ação da LT-A4-H, a qual gera LT-B4 a partir da hidrólise de LT-A4 (HAEGGSTRÖM \& WETTERHOLM, 2002; PENNING et al., 2002; FOULON et al., 1999). Sobretudo, a bifuncionalidade catalítica da APB/LT-A4-H e o seu significado fisiopatológico ainda são pouco conhecidos.

\section{OBJETIVO}

Analisar a inter-relação entre LT-A4-H, APB, LT-B4 e o desenvolvimento e a resistência à indução da AR no modelo CIA em ratos.

\section{ESTRATÉGIAS DE ESTUDO}

- Classificar e agrupar os animais experimentais (ratos) em controles, artríticos e resistentes à indução de artrite no modelo CIA, segundo a formação de edema artrítico, eritema, cianose e título de AACII no plasma e teor de TNF- $\alpha$ no soro;

- Nos homogenatos do tecido sinovial (TS) de animais controles sadios:

- identificar e quantificar a expressão gênica das proteínas EC 3.3.2.6 e EC 3.4.11.6, por meio da reação quantitativa em tempo real em cadeia da polimerase (qPCR);

- No plasma, líquido sinovial (SY), e frações solúvel (FS) e de membrana solubilizada (FM) do TS e de células mononucleares do sangue periférico (PBMCs) de animais de todos os grupos: 
- quantificar proteína para normalizar o cálculo das atividades APB e desidrogenase láctica (LDH), este último um marcador de FS;

- quantificar a atividade APB, por medida espectrofluorimétrica da hidrólise de Larginina $\beta$-naftilamida (ArgNA);

- padronizar, comparar e eleger a metodologia mais adequada, entre cromatografia líquida de alta eficiência (HPLC) e ensaio imunoenzimático (EIA), e utilizá-la para a quantificação do teor de LT-B4 e da atividade LT-A4-H.

\section{MATERIAL E MÉTODOS}

\subsection{Animais e tratamentos}

Ratos Wistar, adultos, machos, 160-180g, mantidos com comida e água ad libitum e sob condições controladas, em gaiolas com até 4 animais, alojadas em estante climatizada $\left(25^{\circ} \mathrm{C}\right.$, umidade relativa $65,3 \pm 0.9 \%$ ), com fotoperíodo de $12 \mathrm{~h}: 12 \mathrm{~h}$ claro:escuro (com início do período claro as 6:00 da manhã), foram submetidos aos procedimentos descritos a seguir, aprovados pela Comissão de Ética no Uso de Animais do Instituto Butantan, sob protocolo ${ }^{\circ}$ $682 / 09$.

Com base no método de CREMER (1998), aqui modificado, $4 \mathrm{mg}$ de CII de galinha (Sigma, USA) diluído em $1 \mathrm{~mL}$ de ácido acético 0,01M e emulsificado em mesmo volume de adjuvante incompleto de Freund (Sigma, USA) (concentração final $=2 \mathrm{mg}$ de CII $/ \mathrm{mL}$ ácido acético $0,01 \mathrm{M}$ e adjuvante) foi administrado em parte dos animais num volume de $200 \mu \mathrm{L}$ (dose: 0,4 mg / 160-180 g massa corporal), via intradérmica (id), no primeiro terço proximal da cauda. Outros animais (controles) receberam $0,9 \% \mathrm{NaCl}$ no mesmo volume, via e local supracitados. Todos os animais que receberam a emulsão ou salina foram previamente anestesiados com solução de cetamina $(3,75 \%)$ (Fort Dodge, USA) e xilazina $(0,5 \%)$ (Vetbrands, Brasil) em dose de 0,2 mL / $100 \mathrm{~g}$ de massa corporal, via intraperitoneal (ip). Todos esses procedimentos supracitados, assim como a avaliação do edema, eritema e cianose, e coleta de material foram realizados no período matinal. 


\subsection{Avaliação do edema das patas}

Foram observados os aspectos de eritema e cianose e quantificada, com um paquímetro (Mitutoyo, EUA), a espessura dorso-plantar das patas posteriores na região do metatarso. Ambas as patas foram medidas e calculou-se a média da espessura para cada animal. A medida dessa espessura foi realizada em dois momentos: no dia da indução por CII nos grupos CIA e injeção de $\mathrm{NaCl}$ nos controles, e no dia da eutanásia e coleta de material para ambos os grupos.

\subsection{Coleta de material}

No $41^{\circ}$ dia após a indução, os animais foram anestesiados, com as mesmas drogas e doses descritas no item 6.1, e submetidos à exsanguinação por punção cardíaca com seringas heparinizadas e não heparinizadas. Parte do sangue heparinizado foi centrifugado a 5.000 rpm, por $10 \mathrm{~min}$, a $4^{\circ} \mathrm{C}$ para separar o plasma. Outra parte do sangue heparinizado foi destinada à obtenção de PBMCs. O soro foi obtido do sangue não heparinizado, após 45 min, a $37^{\circ} \mathrm{C}$, e centrifugação a $200 \mathrm{X}$ g, por $10 \mathrm{~min}$, para a obtenção do soro. Soro e plasma foram armazenados a $-20^{\circ} \mathrm{C}$ e utilizados, em até 10 dias, respectivamente para as medidas de TNF- $\alpha$, teor proteico, atividades APB e LT-A4-H e título de AACII. O SY e o TS foram retirados dos joelhos da seguinte forma: a cavidade articular foi aberta, o ligamento patelar foi cuidadosamente removido e, então, $200 \mu \mathrm{L}$ de $\mathrm{NaCl} 0,9 \%$ estéril foram injetados intraarticulamente, em cada joelho, com seringas com agulhas ultrafinas $(0,45 \times 13 \mathrm{~mm})$. Subsequentemente, o SY, assim diluído, foi aspirado com as mesmas seringas. Depois dessa aspiração, utilizando uma pinça fina e lâmina, o TS foi removido. O TS consistiu da membrana sinovial, juntamente com o tecido conjuntivo e a almofada de gordura da cápsula articular, após a remoção cuidadosa do tecido adiposo ao redor da patela. O SY foi armazenado a $-20^{\circ} \mathrm{C}$ e utilizado em até 10 dias para as medidas do teor proteico e atividades APB e LT-A4-H. O TS também foi armazenado a $-20^{\circ} \mathrm{C}$ e submetido, em até 10 dias, ao fracionamento previsto (FS e FM). Mediante as medidas da espessura das patas, dos níveis de TNF- $\alpha$ no soro e do título de AACII no plasma, os animais foram subdivididos em dois grupos: Artríticos e Resistentes (que não desenvolveram artrite). Após os procedimentos supramencionados os animais foram eutanasiados por decapitação. 


\subsection{Obtenção de Células Mononucleares do Sangue Periférico (PBMCs)}

Baseado no relato de GRAGE-GRIEBENOW et al. (1997), o sangue heparinizado foi cuidadosamente depositado sobre uma solução de Percoll (densidade $=1,077$ g / mL) (GE Healthcare, USA) com PBS (56\%); para cada $5 \mathrm{~mL}$ de sangue coletado foi usado $3 \mathrm{~mL}$ da solução de Percoll e PBS (56\%), sendo centrifugado a $1.000 \mathrm{X} \mathrm{g}$, por $40 \mathrm{~min}$, a $25^{\circ} \mathrm{C}$. A camada de PBMCs (segunda faixa de cima para baixo, aspecto esbranquiçado) foi retirada do tubo com pipetas Pasteur e transferida para microtubos identificados para a realização de contagem destas células.

\subsubsection{Contagem de PBMCs}

A quantificação do número total de PBMCs foi realizada em alíquotas de $20 \mu \mathrm{L}$ de suspensão de células diluídas em líquido de Turk (1:20, v/v), em câmara de Neubauer, ao microscópio óptico.

\subsubsection{Viabilidade de PBMCs}

A viabilidade celular foi avaliada utilizando $40 \mu \mathrm{L}$ de suspensão de células diluídas em Tripan (v/v), em câmara de Neubauer, ao microscópio óptico.

\subsection{Obtenção da FS e da FM do TS e de PBMCs}

O TS dos joelhos de um mesmo animal foi homogeneizado em tampão 10mM Tris-HCl, $\mathrm{pH}$ 7,4, (0,1 g de tecido/ $3 \mathrm{~mL}$ ), por $3 \mathrm{~min}$ a $15.000 \mathrm{rpm}$ (Polytron-Aggregate, Kinematica) e ultracentrifugado a $100.000 \mathrm{X} g$ por $35 \mathrm{~min}$ (Hitachi modelo HIMAC CP60E). O sobrenadante corresponde a FS. Os pellets foram lavados duas vezes com o mesmo tampão (ultracentrifugação a $100.000 \mathrm{X} g$ por $35 \mathrm{~min}$ ), homogeneizados por 3 min a $800 \mathrm{rpm}$ (homogeneizador Tecnal TE 099), em mesmo volume de tampão 10mM Tris-HCl, pH 7,4, acrescido de Triton X-100 (0,1\%). Em seguida, os homogenatos foram ultracentrifugados a $100.000 \mathrm{X} g$ por $35 \mathrm{~min}$. Os sobrenadantes resultantes desta última ultracentrifugação correspondem a FM.

As PBMCs (3,0 x $10^{6}$ células/ mL; viabilidade média de 90\%) foram sonicadas em tampão Tris- $\mathrm{HCl}$ 10mM, pH 7,4, a uma amplitude de 40 por 10 segundos e ultracentrifugadas, conforme o mesmo procedimento descrito no parágrafo anterior, para a obtenção de FS e FM. 
Todos os procedimentos foram realizados a $4^{\circ} \mathrm{C}$. As FS e $\mathrm{FM}$ foram utilizadas para determinar as atividades de APB, LT-A4-H, LDH e teor proteico.

\subsection{Medida de TNF- $\alpha$ e AACII}

O teor de TNF- $\alpha$ no soro e o título de AACII no plasma foram avaliados utilizando kits EIA comerciais (respectivamente, Biosource e Chondrex, USA), segundo as recomendações dos fabricantes.

\subsection{Proteína total}

Foi medida pelo método de BRADFORD (1976) com o kit Bio-Rad (Hercules, USA), utilizando triplicatas de $40 \mu \mathrm{L}$ de amostras de SY e FS (diluída 10 vezes) e FM (diluída duas vezes) de TS e PBMCs, e plasma (diluído 500 vezes), lidas a 630nm em espectrofotômetro leitor de microplaca Bio-Tek Power Wave X® (Bio-Tek Instruments, EUA). O conteúdo de proteína foi interpolado pela comparação com a respectiva curva-padrão obtida com albumina de soro bovino (BSA) (Sigma, St. Louis, USA) dissolvida no mesmo diluente da amostra. Os valores foram utilizados para normalização do cálculo das atividades APB e LDH.

\subsection{Medida de LDH}

Foi realizada de acordo com o método de BERGMEYER \& BRENT (1972). Utilizou-se triplicatas de $3 \mu \mathrm{L}$ de amostras de FS e FM de TS e de PBMCs incubados com $297 \mu \mathrm{L}$ de tampão $100 \mathrm{mM}$ de fosfato, $\mathrm{pH} 7,4$, contendo $200 \mathrm{mM}$ de $\mathrm{NaCl}$ e 1,6mM de solução de piruvato de sódio e $0,2 \mathrm{mM}$ de sal dissódico de nicotinamida adenina dinucleotídeo na forma reduzida (NADH) (Sigma). As leituras foram realizadas espectrofotometricamente a 340nm em leitor de microplaca Bio-Tek Power Wave $X ®$, a primeira no tempo zero e a segunda após 10 min de incubação a $37^{\circ} \mathrm{C}$. A atividade $\mathrm{LDH}$ foi determinada subtraindo-se o valor da leitura, após 10 min de incubação, do obtido no tempo zero e, então, o resultado foi interpolado por comparação com uma curva-padrão de NADH. A atividade LDH foi expressa como mmol NADH oxidado/min/mg proteína. Os valores foram utilizados para avaliar a eficiência do fracionamento do TS e dos PBMCs. 


\subsection{Atividade APB}

Foi medida com base na quantidade de $\beta$-naftilamina liberada pela reação das amostras incubadas com o substrato ArgNA (Sigma). As amostras foram incubadas a $37^{\circ} \mathrm{C}$, por $30 \mathrm{~min}$, em microplacas de 96 poços (Corning Inc., New York, USA), num volume final de $275 \mu \mathrm{L}$ de solução $0,5 \mathrm{mM}$ de substrato em tampão fosfato $0,05 \mathrm{M}, \mathrm{pH} 6,5$, contendo $150 \mathrm{mM} \mathrm{NaCl}$, $0,02 \mathrm{mM}$ puromicina (Sigma) e $0,1 \mathrm{mg} \mathrm{BSA} / \mathrm{mL}$. A quantidade de $\beta$-naftilamina liberada foi estimada fluorimetricamente, utilizando leitor de microplaca (FL600FA, Bio-Tek), no comprimento de onda de emissão de 460/40nm e comprimento de onda de excitação de 360/40nm. O valor da leitura do "branco" do tempo zero de incubação foi subtraído dos valores do incubado de 30 min e o resultado foi interpolado por comparação com a respectiva curva-padrão de $\beta$-naftilamina (Sigma). A atividade catalítica de APB foi expressa como picomoles de substrato hidrolisado/min/mg proteína (ZAMBOTTI-VILLELA et al., 2007).

\subsection{Padronização da medida do LT-A4-H}

\subsubsection{EIA}

\section{Amostras incubadas com LT-A4}

Baseado na metodologia de LIANG et al (2007), $1 \mu \mathrm{L}$ de solução LT-A4 (Sigma)

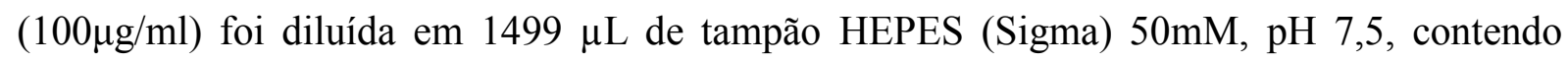
$0,0625 \%$ glicerol e $1 \%$ dimetil sulfóxido (DMSO) (Sigma). Foram pipetados em cada poço da microplaca (96 poços) (Corning) $50 \mu \mathrm{L}$ de amostras de plasma, SY, e FS e FM de TS e de PBMCs e $250 \mu \mathrm{L}$ de solução do tampão supracitado contendo LT-A4 (concentração final de LTA4 $=166,66 \mathrm{nM})$. Essa mistura foi incubada por $10 \mathrm{~min}$ em agitador orbital de microplacas a $25^{\circ} \mathrm{C}$, sob constante agitação (250 rpm). Após a incubação, $10 \mu \mathrm{L}$ de cada incubado foram transferidos para microtubo contendo $190 \mu \mathrm{L}$ do tampão de ensaio gelado (EIA buffer) do kit de EIA para LT-B4. Os $290 \mu \mathrm{L}$ restantes de cada incubado foram transferidos para microtubos e armazenados a $-80^{\circ} \mathrm{C}$, para serem posteriormente aplicados em HPLC, do qual se coletou o pico obtido no tempo de retenção (RT) do LT-B4 que, por sua vez, também teve seu conteúdo de LT-B4 medido por EIA. 


\section{Amostras sem adição de LT-A4}

Foram diluídas na mesma quantidade e forma descrita acima, mas sem a adição de LT-A4, e da mesma forma assim incubadas e submetidas à medida de LT-B4 pelo kit de EIA ou à cromatografia em HPLC, do qual se coletou o pico obtido no RT do LT-B4 que, por sua vez, também teve seu conteúdo de LT-B4 medido por EIA.

\section{Procedimento de EIA}

As amostras, obtidas como descrito acima, foram submetidas à leitura de absorbância em $\lambda=412 \mathrm{~nm}$, conforme instruções do fabricante do kit EIA para LT-B4 (Leukotriene B4 EIA kit; Cayman Chemical, USA). Foram utilizadas duas soluções do tampão HEPES, com e sem LT-A4, ambas sem amostras, submetidas às mesmas condições da incubação supracitadas, para leitura do "branco" da reação contra o "branco" fornecido no kit.

\subsubsection{HPLC}

\section{Extração de LT-B4 por fase sólida}

Em conformidade com instruções do manual do kit de EIA, amostras incubadas ou não com LT-A4 e destinadas à passagem no HPLC foram acidificadas com ácido fórmico $1 \mathrm{M}$ $(\mathrm{pH}=3,5)$ e aplicadas em microcolunas Sep-Pak C18 (Waters, Irlanda) previamente equilibradas, sequencialmente, com $5 \mathrm{~mL}$ de metanol e $5 \mathrm{~mL}$ de água deionizada. Após a passagem da amostra, a coluna foi lavada com $5 \mathrm{~mL}$ de água deionizada e $5 \mathrm{~mL}$ de hexano e mantida 5 min a $25^{\circ} \mathrm{C}$. Subsequentemente o LT-B4 foi eluído com $5 \mathrm{~mL}$ de etil acetato em $1 \%$ de metanol (99:1 v/v), sendo este eluato aliquotado e seco em SpeedVac (TAKAMOTO et al., 1995). Após secagem, o material foi armazenado a $-20^{\circ} \mathrm{C}$ até sua passagem no HPLC.

\section{Procedimento cromatográfico}

Foi utilizada coluna analítica $(4,6 \mathrm{~mm}$ X $25 \mathrm{~cm}$, partículas de $5 \mu \mathrm{m}$ de diâmetro) $\mathrm{C} 18 \mathrm{de}$ fase reversa (Shimadzu, Japão). O LT-B4 (Cayman, USA) foi utilizado como padrão para determinação do RT. As amostras desidratadas e armazenadas obtidas na extração por SepPak foram dissolvidas em $130 \mu \mathrm{L}$ de solução (10 : $10: 30: 50)$ metanol : tetrahidrofurano : acetonitrila : $\mathrm{H}_{2} \mathrm{O}$ deionizada e aplicadas na coluna em volume de $40 \mu \mathrm{L}$. As condições de análise cromatográfica foram as seguintes: corrida isocrática de $20 \mathrm{~min}$ com $100 \%$ solução (30 : $30: 40: 0,01)$ metanol : acetonitrila : $\mathrm{H}_{2} 0$ deionizada : ácido acético, fluxo de 0,8 $\mathrm{mL} / \mathrm{min}$, monitorada a $\lambda=270 \mathrm{~nm}$ (RUDBERG et al., 2002) com detector UV acoplado ao 
equipamento (Shimadzu Prominence, Japão). A quantidade de LT-B4 nas amostras foi determinada pela área dos picos obtidos no mesmo RT do LT-B4 comercial padrão (Cayman Chemical, USA), por interpolação numa curva-padrão (Figura 2).

\subsubsection{Teor de LT-B4}

Foi mensurado por interpolação do valor das áreas dos picos em curva-padrão (Figura 3) construída com concentrações conhecidas do padrão LT-B4 cromatografado em HPLC nas mesmas condições das amostras, e por interpolação do valor de leituras de absorbância em curva-padrão (Figura 4) construída com concentrações conhecidas de padrão de LT-B4 no kit comercial EIA.

\subsubsection{Atividade LT-A4-H}

Expressa pela medida (por EIA e HPLC) de LT-B4 (produto de hidrólise do LT-A4 pela LT-A4-H) formado em $1 \mathrm{~min}$ por $1 \mathrm{~mL}$ de amostra, calculada pelo resultado da subtração do teor de LT-B4 em amostras brutas (sem incubar com LT-A4) do teor de LT-B4 em amostras incubadas com LT-A4.

\subsection{Expressão gênica da APB e da LT-A4-H}

\subsubsection{Extração do RNA}

O RNA da suspensão de TS de cada animal controle sadio foi extraído utilizando o RiboPure $^{\mathrm{TM}}$ Kit (Applied Biosystems, EUA), conforme recomendado pelo fabricante. Em resumo, a amostra foi homogeneizada sobre gelo com TriReagent ${ }^{\circledR}$ (Applied Biosystems, EUA) ( $1 \mathrm{~mL}$ de TriReagent ${ }^{\circledR}$ para cada 0,05 a $0,1 \mathrm{mg}$ de tecido inicial), em Poly Tron® a $11.000 \mathrm{rpm}$ e, sequencialmente, foram incubadas por $5 \mathrm{~min}$ a $25^{\circ} \mathrm{C}$ e centrifugadas a $12.000 \mathrm{X}$ $g$, por $10 \mathrm{~min}$ a $4^{\circ} \mathrm{C}$. Para cada $1 \mathrm{~mL}$ de amostra, foi adicionado $200 \mu \mathrm{L}$ de clorofórmio, misturando em agitador vortex por 15 segundos. As amostras foram incubadas por 5 min a $25^{\circ} \mathrm{C}$ e depois centrifugadas a $12.000 \mathrm{Xg}$, por $10 \mathrm{~min}$ a $4^{\circ} \mathrm{C}$. Após centrifugação, o RNA se encontra na fase aquosa, enquanto o DNA e as proteínas estão presentes na interfase e na fase fenol. $400 \mu \mathrm{L}$ da fase aquosa foram transferidos para um novo tubo, misturados com $200 \mu \mathrm{L}$ de etanol absoluto $(99,9 \%)$, homogeneizados no vortex por 15 min e transferidos para um complexo filtro-tubo coletor (fornecido com o kit). O complexo filtro-tubo coletor foi centrifugado a $12.000 \mathrm{X} g$, por 30 segundos a $25^{\circ} \mathrm{C}$; o líquido que escoou para o tubo coletor foi descartado, e o filtro colocado no mesmo tubo coletor; o RNA está ligado ao filtro. Foram 
aplicados $500 \mu \mathrm{L}$ de solução de lavagem (fornecida com o kit) ao complexo filtro-tubo coletor. A lavagem e a centrifugação foram repetidas mais uma vez e o líquido que escoou foi descartado novamente. Então, o complexo filtro-coletor foi centrifugado a $12.000 \mathrm{X} g$ por 30 segundos a $25^{\circ} \mathrm{C}$, para remover resíduos da solução de lavagem. O filtro foi transferido para um novo tubo coletor e foram adicionados $100 \mu \mathrm{L}$ de tampão de eluição (fornecido com o kit) na coluna do filtro, seguido de uma incubação de $2 \mathrm{~min}$ a $25^{\circ} \mathrm{C}$. Após incubação, o complexo filtro-tubo coletor foi centrifugado a $12.000 \mathrm{X} g$, por 30 segundos, a $25^{\circ} \mathrm{C}$. O RNA recuperado foi armazenado a $-20^{\circ} \mathrm{C}$.

\subsubsection{Transcrição Reversa (construção da fita de DNA complementar - cDNA)}

A expressão da APB, LT-A4-H e GAPDH foi avaliada utilizando qPCR.

Cada tubo contendo RNA total foi tratado com $1 \mu \mathrm{L}$ de TURBOTM DNase (2U) para até $10 \mu \mathrm{g}$ de RNA em $50 \mu \mathrm{L}$ de reação, por $30 \mathrm{~min}$ a $37^{\circ} \mathrm{C}$. Foi adicionado EDTA $15 \mathrm{mM}$ na solução de RNA, a qual foi aquecida a $75^{\circ} \mathrm{C}$, por $10 \mathrm{~min}$, para inativar a DNase. Foram utilizados até $2 \mu \mathrm{g}$ de RNA (contidos em no máximo $9 \mu \mathrm{L}$ ) para a transcrição reversa utilizando o High Capacity RNA-to-cDNA Kit (Applied Biosystems, EUA). Foram adicionados $10 \mu \mathrm{L}$ de tampão de reação (fornecido com o kit), $1 \mu \mathrm{L}$ de mix de enzima (fornecido com o kit) e o volume foi completado para $20 \mu \mathrm{L}$ com água DEPC (dietilpirocarbonato). As amostras foram colocadas no termociclador, por $60 \mathrm{~min}$, a $37^{\circ} \mathrm{C}$, seguido por $5 \mathrm{~min}, \mathrm{a} 95^{\circ} \mathrm{C}$. Depois disso, as amostras foram armazenadas a $-80^{\circ} \mathrm{C}$.

\subsection{3. $q P C R$}

Foi utilizado o sistema Taqman, empregando-se, além dos pares de primers, uma sonda que se hibridiza de forma específica com a fita molde de cDNA antes do par de primers. As condições do termociclador para a reação de PCR foram: 1 ciclo de 2 min a $50^{\circ} \mathrm{C}, 1$ ciclo de 10 min a $95^{\circ} \mathrm{C}$, seguido de 40 ciclos: 15 segundos a $95^{\circ} \mathrm{C}$ e 1 min a $60^{\circ} \mathrm{C}$. Foram utilizados primers e sonda da APB com ID: Rn 00579477_m1 ( ${ }^{\circ}$ de acesso ao GenBank: NM_020216), da LT-A4-H com ID Rn01503878_m1 ( ${ }^{\circ}$ de acesso ao GenBank: NM_001030031). Como controle positivo, foi utilizado o GAPDH $\left(\mathrm{N}^{\circ}\right.$ de acesso ao GenBank: NM_017008). Todos os primers e sondas supracitados são da Life Technologies (Brasil).

No método comparativo, para expressão relativa de um gene-alvo em comparação a um gene de referência e baseado na eficiência dos primers (PFAFFL, 2001), a quantidade do gene-alvo foi normalizada a um controle endógeno e calculada em relação ao calibrador, o 
qual é a amostra com maior cycle threshold (menor expressão gênica) e que foi utilizada como base para os resultados comparativos.

\subsection{Análise dos resultados}

Os resultados foram apresentados como média \pm erro padrão da média (EPM) e analisados estatisticamente usando o programa computacional GraphPad Prism®. Análise de regressão foi usada para obtenção de curvas-padrão de proteína, NADH, $\beta$-naftilamina e LT-B4. O teste " $t$ " de Student foi utilizado para comparar valores de edema da pata e parâmetros entre amostras com e sem incubação com LT-A4 e valores de LDH entre FS e FM. Para comparar valores entre os grupos controle, artrítico e resistente foi utilizada a análise de variância ANOVA, seguida por teste post-hoc Newman-Keuls para múltiplas comparações, quando foram detectadas diferenças no ANOVA. Em todos os cálculos foi adotado o nível crítico $\mathrm{p}<0,05$.

\section{RESULTADOS}

\subsection{Classificação dos animais pela suscetibilidade à indução de artrite}

O edema (em mm; n=número de animais, teste $\mathrm{t}$ de Student não-pareado bicaudal $\mathrm{p}<0,0017$ ), bem como o eritema e a cianose, caracterizaram macroscopicamente as patas posteriores dos artrítico. O edema foi encontrado em grau severo $(5,899 \pm 0,037 ; n=10)$ em $60 \%$ dos animais tratados com CII. 30\% dos animais tratados com CII não apresentaram edema $(4,762 \pm 0,309 ; \mathrm{n}=10)$, eritema ou cianose, comparativamente aos controles $(4,745 \pm 0,052 ; n=10)$. O teor de TNF- $\alpha(e m p g / m L ; n=$ número de animais; ANOVA $p<0,001$; teste post hoc Student-Newman-Keuls $\mathrm{p}<0,001)$ no soro é detectável $(21,1 \pm 1,2 ; n=4)$ somente nos animais com edema artrítico severo, sendo igualmente indetectável nos animais tratados com CII que não apresentaram nenhum grau de edema e nos controles. Os títulos de AACII no plasma (em $\mu \mathrm{g} / \mathrm{mL}$; $\mathrm{n}=$ número de animais; ANOVA $\mathrm{p}<0,001$; teste post hoc StudentNewman-Keuls $\mathrm{p}<0,001)$ são marcadamente elevados tanto nos animais tratados com CII que não apresentaram nenhum grau de edema $(191 \pm 1,5 ; n=3)$, quanto nos que apresentaram 
edema artrítico severo $(186 \pm 5,7 ; n=3)$, comparativamente aos controles $(0,039 \pm 0,018 ; n=2)$. Portanto, considerando o conjunto de critérios supramencionados, puderam ser seguramente agrupados como artríticos os animais tratados com CII que apresentaram edema e níveis detectáveis de TNF- $\alpha$ no soro e como resistentes à indução de artrite os animais tratados com CII que não apresentaram edema.

\subsection{Eficiência do fracionamento do TS e de PBMCs}

Em todos os grupos sob estudo a atividade LDH ( $\mathrm{n}=$ número de animais; teste $\mathrm{t}$ de Student não-pareado, bicaudal, $\mathrm{p}<0,0001)$ foi detectada somente na FS do TS dos animais controles $(0,3633 \pm 0,0071 ; n=6)$, artríticos $(0,9383 \pm 0,0094 ; n=6)$ e resistentes $(0,8633 \pm 0,0088 ; n=6)$ e na FS de PBMCs dos animais controles $(0,4417 \pm 0,01014 ; n=6)$, artríticos $(0,1058 \pm 0,001851$; $\mathrm{n}=6)$ e resistentes $(0,9217 \pm 0,02212 ; \mathrm{n}=6)$, sendo nula na FM tanto do TS quanto de PBMCs.

\subsection{Expressão gênica de APB (EC 3.4.11.6) e de LT-A4-H (EC 3.3.2.6)}

A Figura 2 mostra que os genes da APB (EC 3.4.11.6) e da LT-A4-H (EC 3.3.2.6) são expressos no TS de animais controles sadios.

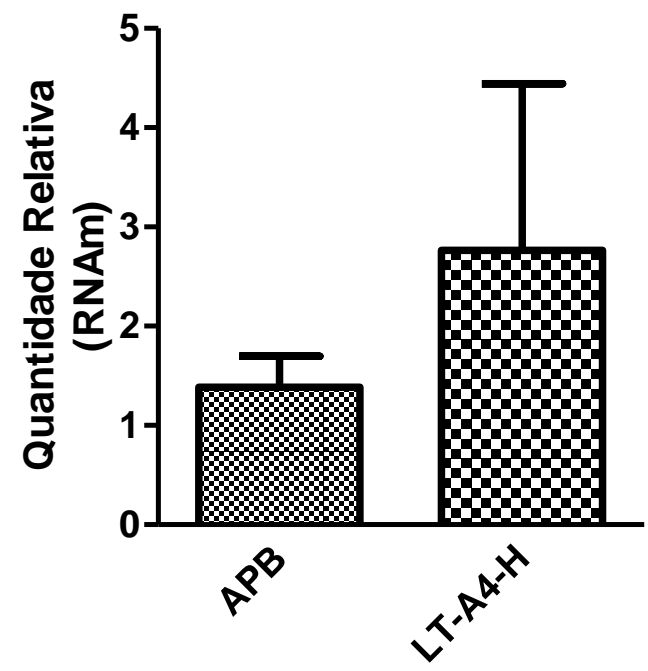

Figura 2. Expressão gênica relativa de aminopeptidase básica (APB) (EC 3.4.11.6) e LT-A4 hidrolase (LT-A4-H) (EC 3.3.2.6) em tecido sinovial de ratos controles sadios. Número de animais $=2$. 


\subsection{Atividade APB}

A Tabela 1 mostra a atividade APB no plasma, SY e FS e FM do TS e de PBMCs. Comparado aos controles esta atividade é menor no plasma e SY e maior na FM de PBMCs nos resistentes, sendo maior na FS e FM do TS dos animais artríticos. A atividade APB na FS de PBMCs é menor em animais artríticos-CIA e resistentes-CIA, em relação aos controles.

Tabela 1 - Atividade APB no plasma, líquido sinovial (SY), frações solúvel (FS) e de membrana solubilizada (FM) do tecido sinovial (TS) e de células mononucleares do sangue periférico (PBMCs) de ratos controles, artríticos e resistentes.

\begin{tabular}{|c|c|c|c|c|}
\hline Amostras & Controle & Artrítico & Resistente & ANOVA \\
\hline Plasma & $136 \pm 4(8)^{\mathrm{a}}$ & $140 \pm 6(9)^{\mathrm{a}}$ & $121 \pm 3(9)^{\mathrm{b}}$ & $\mathrm{p}=0,0159$ \\
\hline SY & $793 \pm 45(8)^{\mathrm{a}}$ & $714 \pm 135(8)^{\mathrm{a}}$ & $398 \pm 45(5)^{\mathrm{b}}$ & $\mathrm{p}=0,0397$ \\
\hline FS - TS & $1583 \pm 211(5)^{\mathrm{a}}$ & $2650 \pm 313(7)^{\mathrm{b}}$ & $1159 \pm 203(9)^{\mathrm{a}}$ & $\mathrm{p}=0,0014$ \\
\hline FM - TS & $3727 \pm 663(6)^{\mathrm{a}}$ & $6887 \pm 997(6)^{\mathrm{b}}$ & $4573 \pm 332(6)^{\mathrm{a}}$ & $\mathrm{p}=0,0192$ \\
\hline FS - PBMCs & $1162 \pm 96(7)^{\mathrm{a}}$ & $430 \pm 20(7)^{\mathrm{b}}$ & $484 \pm 99(6)^{\mathrm{b}}$ & $\mathrm{p}=0,0046$ \\
\hline FM - PBMCs & $347 \pm 38(9)^{\mathrm{a}}$ & $329 \pm 31(9)^{\mathrm{a}}$ & $773 \pm 71(6)^{\mathrm{b}}$ & $\mathrm{p}<0,0001$ \\
\hline
\end{tabular}

Valores são média_EPM. Número de animais entre parênteses, valores de cada animal medidos em duplicata. Análise de variância ANOVA, Student-Newman-Keuls, p<0,05: Controle vs Artrítico vs Resistente para uma mesma amostra (letras diferentes na mesma linha indicam diferença significativa).

\subsection{Teor de LT-B4 e atividade LT-A4-H}

\section{Padronização da medida}

A Figura 3 ilustra uma corrida cromatográfica típica do padrão LT-B4 (em vermelho) e de material biológico (em preto). Em cada corrida foram coletadas, em pool, frações no intervalo de 11,5 a 13,5 min perfazendo um total de 1,6 $\mathrm{mL}$, sendo seco e assim mantido a $-80^{\circ} \mathrm{C}$ até ser utilizado. 


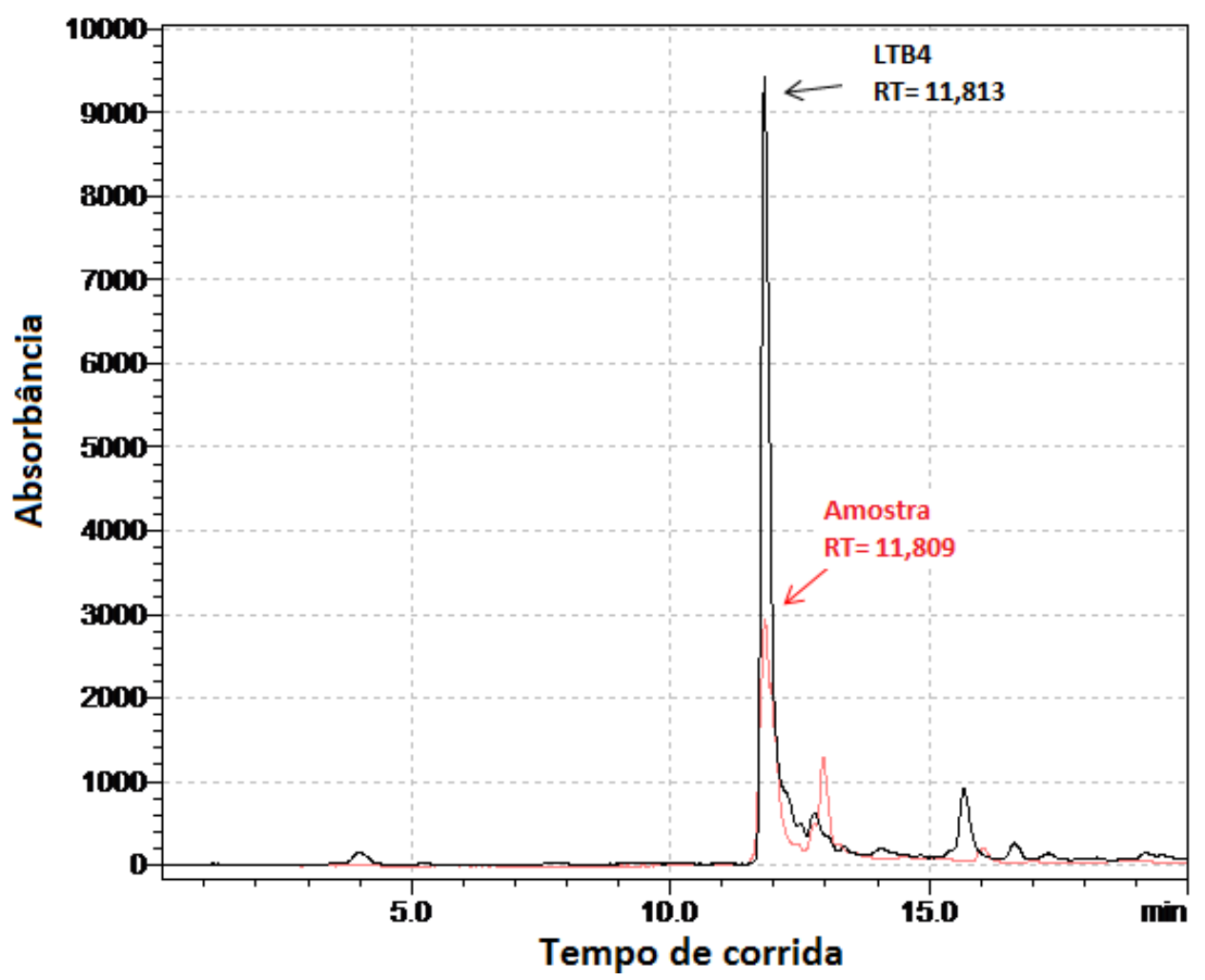

Figura 3. Corrida típica em HPLC (C18 de fase reversa, corrida isocrática de 20 min com $100 \%$ solução de $30: 30: 40: 0,01$ metanol : acetonitrila : $\mathrm{H}_{2} 0$ deionizada : ácido acético, monitorada em $\lambda=270 \mathrm{~nm}$, num fluxo de $0,8 \mathrm{~mL} / \mathrm{min})$ de padrão LT-B4 33,33 pg/mL $(0,4$ $\mu \mathrm{M})$ (em preto) e amostra de líquido sinovial de animal artrítico incubado com LT-A4 (em vermelho). O mesmo aspecto ocorreu para as demais amostras e grupos sob estudo.

A Figura 4 ilustra a curva-padrão relacionando áreas dos picos obtidos com as concentrações conhecidas de LT-B4 injetadas no HPLC. O teor desconhecido de LT-B4 em amostras foi obtido por interpolação dos valores de área dos picos obtidos no mesmo RT do LT-B4 padrão.

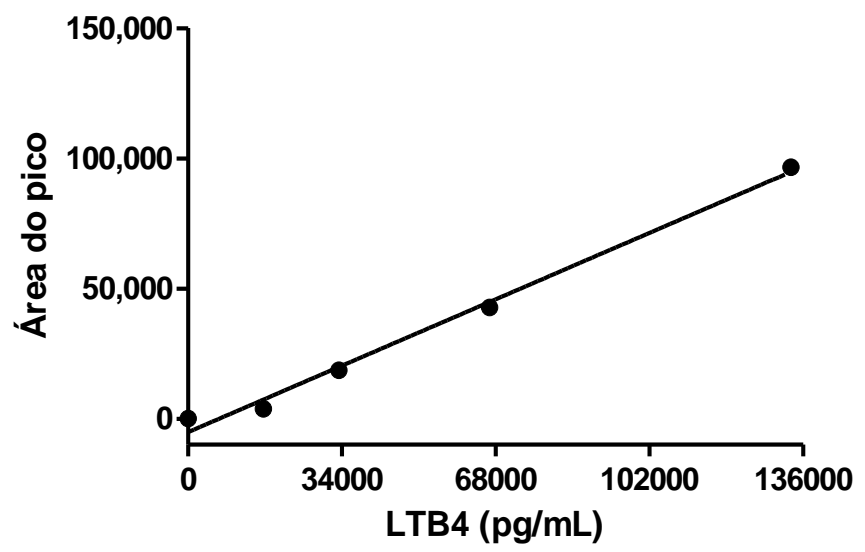

Figura 4. Regressão linear entre níveis de LT-B4 e áreas dos picos correspondentes no HPLC. Slope $=0,7496 \pm 0,0383, r^{2}=0,9922, p=0,0003$. 
A Figura 5 ilustra a curva-padrão do EIA relacionando a leitura de absorbância em $\lambda=412 \mathrm{~nm}$ (kit) com concentrações de LT-B4 em pg/mL. O teor desconhecido de LT-B4 em amostras foi obtido por interpolação dos valores de absorbância obtidos no EIA.

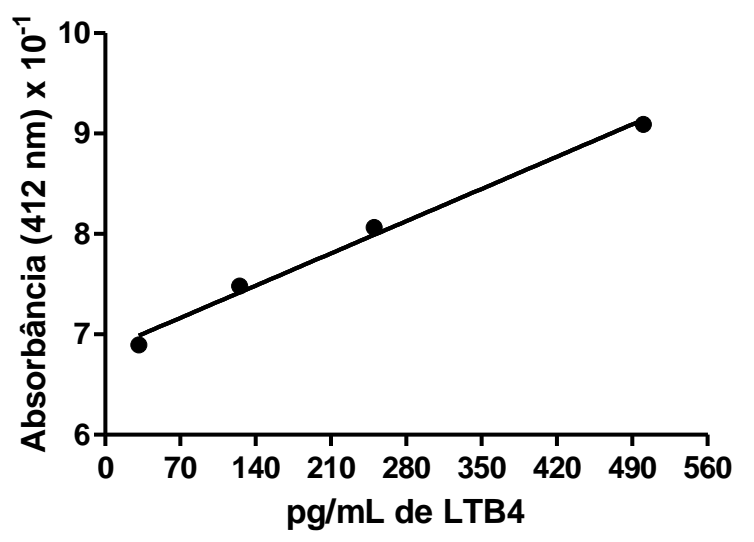

Figura 5. Regressão linear entre níveis de LT-B4 e valores de absorbância em $\lambda=412 \mathrm{~nm}$ obtidos no EIA. Slope $=0,0046 \pm 0,0003, \mathrm{r}^{2}=0,9923, \mathrm{p}=0,0038$.

A Figura 6-I ilustra a análise de regressão entre valores de concentrações de LT-B4 padrão dos picos obtidos no HPLC que foram medidos no EIA, mostrando a ausência de correlação e, portanto, que algum fator existente nos picos coletados e secos interfere na qualidade do EIA. A Figura 6-II ilustra a análise de regressão entre valores de concentrações de LT-B4 dos picos obtidos no HPLC e que foram medidos no EIA e de medida direta no EIA de todas as amostras avaliadas neste estudo, confirmando a ausência de correlação observada na Figura 6-I e a existência de fator interferente na qualidade do EIA nos picos coletados do HPLC e secos.

I

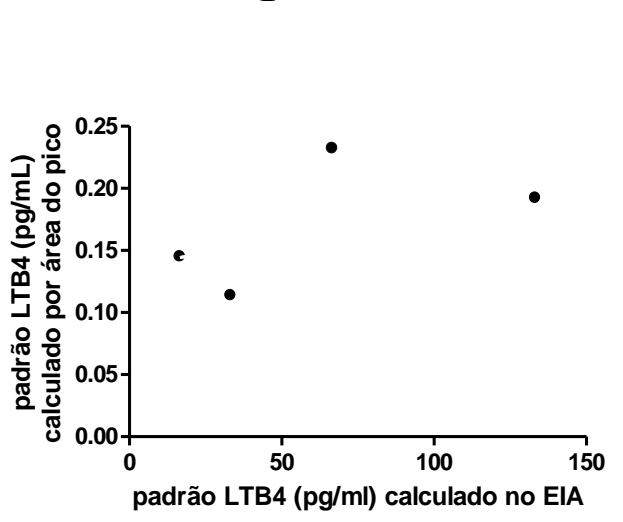

II

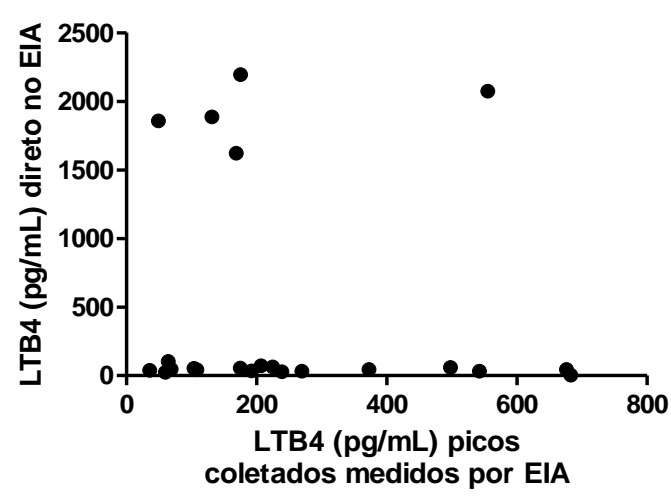

Figura 6. Análise de regressão comparativa. Em (I), padrão LT-B4 coletado nos picos do HPLC medido por área do pico versus medido por EIA; slope $=0,0006 \pm 0,0006, \mathrm{r}^{2}=0,3280$, $\mathrm{p}=0,4273$. Em (II), teor de LT-B4 dos picos obtidos no HPLC medidos no EIA versus medida direta no EIA de todas as amostras avaliadas neste estudo antes e após passagem no HPLC $(n=36)$; slope $=-0,3592 \pm 0,8776, r^{2}=0,0083, p=0,6867$. 
Embora tenha sido evidenciado na Figura 6 que algum interferente afeta a medida por EIA nos picos coletados do HPLC, a Figura 7 mostra que há consistente correlação linear entre as concentrações de LT-B4 obtidas pela área dos picos do HPLC e as concentrações de LT-B4 obtidas pelo EIA em todas as amostras avaliadas neste estudo, indicando que ambas as metodologias são eficazes na medida do teor de LT-B4.

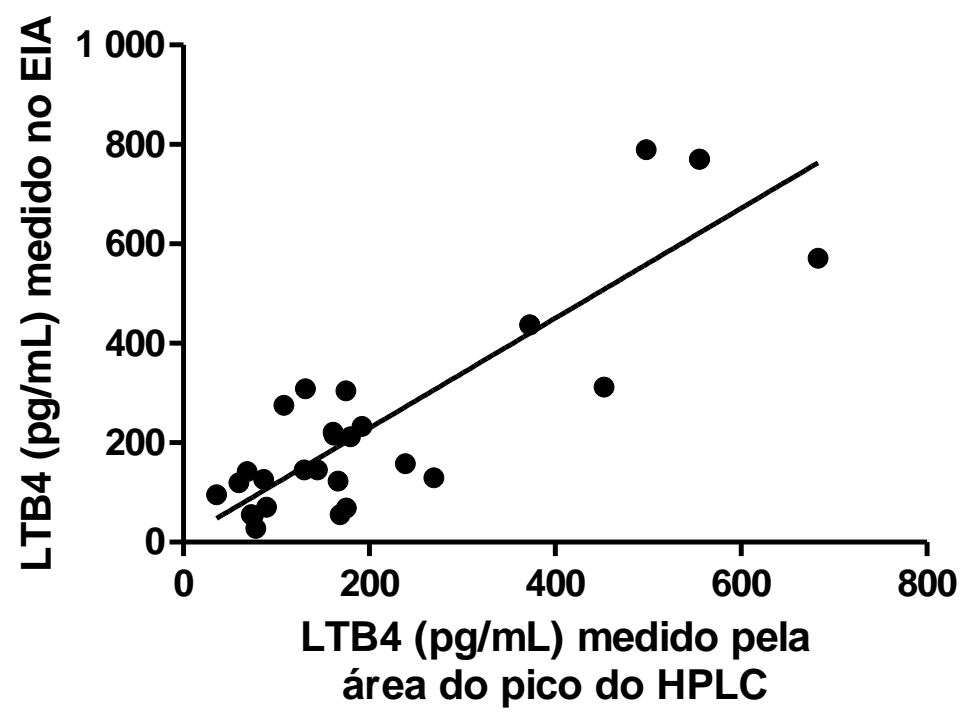

Figura 7. Regressão linear entre os níveis de LT-B4 em todas as amostras sob estudo $(\mathrm{n}=36)$, medidos por área do pico do HPLC e por EIA; slope $=1,106 \pm 0,1207 ; \mathrm{r}^{2}=0,7566 ; \mathrm{p}<0,0001$.

A Tabela 2 mostra os níveis do conteúdo de LT-B4. De um modo geral, como esperado pela correlação (Figura 7), há equivalência entre os valores de concentração de LT-B4 obtidos pela medida da área do pico das corridas em HPLC e pela medida direta por EIA, tanto nas amostras incubadas, como nas sem incubação com LT-A4. Ambos os valores obtidos por EIA foram usados para calcular a atividade LT-A4-H (Tabela 3). Os valores de EIA sem incubação com LT-A4 refletem o conteúdo de LT-B4 endógeno das amostras, o qual comparado aos controles é maior no SY e FM do TS e menor na FS de TS e na FM de PBMCs de artríticos e resistentes, e menor na FS de PBMCs de resistentes (Tabela 2). 
Tabela 2 - Níveis de LT-B4 (pg/mL), medidos por área dos picos do HPLC e por EIA direto, nas amostras de plasma, líquido sinovial (SY), e frações solúvel (FS) e de membrana solubilizada (FM) do tecido sinovial (TS) e de células mononucleares do sangue periférico (PBMCs) de ratos controles, artríticos e resistentes, incubadas (inc) ou não (s-inc) com LT-A4

\begin{tabular}{|c|c|c|c|c|c|c|}
\hline \multicolumn{3}{|c|}{ Amostras } & Controle & Artrítico & Resistente & ANOVA \\
\hline \multirow{5}{*}{ PLASMA } & \multirow{2}{*}{ s-inc } & HPLC & $144,166 \pm 3,998^{\mathrm{a}}$ & $179,679 \pm 2,221^{\mathrm{b}}$ & $166,335 \pm 10,255^{\mathrm{ab}}$ & $\mathrm{p}=0,0271$ \\
\hline & & EIA & $145,38 \pm 0,646^{\mathrm{a}}$ & $211,92 \pm 20,778^{\mathrm{b}}$ & $213 \pm 12,46^{\mathrm{b}}$ & $\mathrm{p}=0,0223$ \\
\hline & & & & & & \\
\hline & \multirow{2}{*}{ inc } & HPLC & $161,843 \pm 3,939^{\mathrm{a} *}$ & $452,467 \pm 14,773^{\mathrm{b} * * *}$ & $160,896 \pm 3,722^{a}$ & $\mathrm{p}<0,0001$ \\
\hline & & EIA & $215,7 \pm 30,3$ & $312,3 \pm 6,3^{\circ}$ & $221,4 \pm 28,8$ & $\mathrm{p}=0,1126$ \\
\hline \multirow{5}{*}{ SY } & \multirow{2}{*}{ s-inc } & HPLC & $78,059 \pm 11,817$ & $73,153 \pm 4,878$ & $75,277 \pm 10,171$ & $\mathrm{p}=0,8779$ \\
\hline & & EIA & $28,32 \pm 3,696^{\mathrm{a}}$ & $55,2 \pm 6,06^{\mathrm{b}}$ & $53,76 \pm 8,58^{\mathrm{b}}$ & $\mathrm{p}=0,0214$ \\
\hline & & & & & & \\
\hline & \multirow{2}{*}{ inc } & HPLC & $89,575 \pm 1,723^{\mathrm{a}}$ & $86,384 \underline{2} 2,049^{\mathrm{a}}$ & $515,347 \pm 15,422^{b_{* *}}$ & $\mathrm{p}<0,0001$ \\
\hline & & EIA & $70,83 \pm 8,712^{\circ \circ * * * *}$ & $126,42 \pm 34,5^{\circ \circ}$ & $169,2 \pm 16,236^{\circ}$ & $\mathrm{p}=0,0577$ \\
\hline & & & & & & \\
\hline \multirow{5}{*}{ FS-TS } & \multirow{2}{*}{ s-inc } & HPLC & $37,665 \pm 4,998^{\mathrm{a}}$ & $49,908 \pm 9,373^{\mathrm{b}}$ & $48,941 \pm 16,340^{\mathrm{a}}$ & $\mathrm{p}=0,7208$ \\
\hline & & EIA & $403,84 \pm 7,2^{a_{\circ} \circ \circ}$ & $145,2 \pm 26,22^{b}$ & $183,6 \pm 56,04^{\mathrm{b}}$ & $\mathrm{p}=0,0090$ \\
\hline & & & & & & \\
\hline & \multirow{2}{*}{ inc } & HPLC & $103,845 \pm 4,705^{\mathrm{a} *}$ & $108,249 \pm 1,317^{\mathrm{b} * * * *}$ & $64,241 \pm 1,039^{\mathrm{c}}$ & $\mathrm{p}=0,0030$ \\
\hline & & EIA & $597,9 \pm 34,5^{\text {aоo }}$ & $275,76 \pm 19,38^{\mathrm{bo}}$ & $360,6 \pm 18,6^{\text {boo }}$ & $\mathrm{p}=0,0016$ \\
\hline & & & & & & \\
\hline \multirow{3}{*}{ FM-TS } & \multirow{2}{*}{ s-inc } & HPLC & $35,999 \pm 6,663^{\mathrm{a}}$ & $238,997 \pm 7,575^{\mathrm{b}}$ & $59,862 \pm 0_{2} 145^{\mathrm{a}}$ & $\mathrm{p}=0,0003$ \\
\hline & & EIA & $95,4 \pm 0,6^{\text {a。 }}$ & $158,1 \pm 3,9^{\text {bo }}$ & $119,4 \pm 0,6^{\text {co०o }}$ & $\mathrm{p}=0,0007$ \\
\hline & inc & HPLC & $68,688 \pm 3,093^{*}$ & $269,401 \pm 1,890$ & $131,357 \pm 0,928 * * *$ & $\mathrm{p}<0,0001$ \\
\hline
\end{tabular}




\begin{tabular}{|c|c|c|c|c|c|c|}
\hline & & EIA & $141,96 \pm 13,44^{\mathrm{a} o}$ & $129,42 \pm 21,78^{\text {ao }}$ & $308,82 \pm 44,94^{\mathrm{b} * * * *}$ & $\mathrm{p}=0,0093$ \\
\hline \multirow{5}{*}{ FS-PBMCs } & \multirow{2}{*}{ s-inc } & HPLC & $206,8 \pm 1,727^{\mathrm{a}}$ & $224,7 \pm 0,291^{\mathrm{b}}$ & $372,6 \pm 0,7412^{\mathrm{c}}$ & $\mathrm{p}<0,0001$ \\
\hline & & EIA & $716,3 \pm 14,09^{\text {aooo }}$ & $697,5 \pm 16,8^{\text {aоo० }}$ & $436,8 \pm 13,86^{\text {bo }}$ & $\mathrm{p}<0,0001$ \\
\hline & & & & & & \\
\hline & \multirow{2}{*}{ inc } & HPLC & $682,8 \pm 0,3066^{\mathrm{a} * * * *}$ & $555,3 \pm 17,12^{\mathrm{b} * * * *}$ & $676,4 \pm 17,02^{\mathrm{a} * * * *}$ & $\mathrm{p}=0,0010$ \\
\hline & & EIA & $571,2 \pm 56,12^{\mathrm{a}}$ & $770,7 \pm 16,92^{\text {boo }}$ & $2973 \pm 31,47^{\mathrm{coo} *} * * * *$ & $\mathrm{p}<0,001$ \\
\hline & & & & & & \\
\hline \multirow{5}{*}{ FM-PBMCs } & \multirow{2}{*}{ s-inc } & HPLC & $174,8 \pm 2,265$ & $168,6 \pm 2,891$ & $175,6 \pm 0,1324$ & $\mathrm{p}=0,1117$ \\
\hline & & EIA & $304,5 \pm 63,57^{\mathrm{a}}$ & $55,5 \pm 5,023^{\text {booo }}$ & $68,4 \pm 2,078^{\text {booo }}$ & $\mathrm{p}=0,0051$ \\
\hline & & & & & & \\
\hline & \multirow{2}{*}{ inc } & HPLC & $497,5 \pm 0,9772^{a} * * *$ & $542,4 \pm 24,95^{\text {a**** }}$ & $192,2 \pm 3,359^{\mathrm{b}} * * *$ & $\mathrm{p}<0,0001$ \\
\hline & & EIA & $789,3 \pm 280,5^{\mathrm{a} \circ \circ * *}$ & $248,4 \pm 94,2^{\text {boo }}$ & $232,8 \pm 7,2^{\text {boo**** }}$ & $\mathrm{p}<0,001$ \\
\hline
\end{tabular}

Valores são média_EPM. Número de animais=3; valores de cada animal medidos em duplicata.

Student-Newman-Keuls, p<0,05: Controle vs Artrítico vs Resistente para uma mesma amostra, para valores estimados por HPLC ou EIA, incubada e sem incubar (letras diferentes na mesma linha indicam diferença significativa).

HPLC: $* \mathrm{p}<0,05 ; * * \mathrm{p}<0,008$, *** $\mathrm{p}<0,001$ em relação a amostra incubada do mesmo grupo (teste t-Student não pareado, bicaudal).

EIA: $* * \mathrm{p}<0,007 ; * * * \mathrm{p}<0,0007$ em relação a amostra incubada de um mesmo grupo (teste t-Student não pareado, bicaudal).

Comparação entre as diferentes metodologias (HPLC e EIA) da mesma amostra incubada e sem incubar: ${ }^{\circ} \mathrm{p}<0,05 ;{ }^{\circ} \mathrm{p}<0,008,{ }^{\circ 00} \mathrm{p}<0,008$, teste tStudent não pareado, bicaudal. 
A Tabela 3 mostra a atividade LT-A4-H in vitro do plasma, SY e de FS e FM do TS e de PBMCs (calculada pela subtração pareada do valor de cada amostra sem incubação daquele após incubação com LT-A4, obtidos por medida direta no EIA - vide Tabela 2). Comparado aos controles, esta atividade é maior no SY e FS de PBMCs e menor na FM de PBMCs de artríticos e resistentes, e maior na FM do TS dos animais resistentes.

Tabela 3 - Atividade LT-A4-H (pg de LT-B4 formado / $\mathrm{min} / \mathrm{mL}$ ) do plasma, líquido sinovial (SY) e frações solúvel (FS) e de membrana solubilizada (FM) do tecido sinovial (TS) e de células mononucleares do sangue periférico (PBMCs) de ratos controles, artríticos e resistentes.

\begin{tabular}{|c|c|c|c|c|}
\hline Amostras & Controle & Artrítico & Resistente & ANOVA \\
\hline PLASMA & $7,03 \pm 0,26$ & $9,73 \pm 1,12$ & $9,84 \pm 1,27$ & $\mathrm{p}=0,1540$ \\
\hline SY & $4,26 \pm 0,29^{\mathrm{a}}$ & $7,12 \pm 0,45^{\mathrm{b}}$ & $15,11 \pm 1,01^{\mathrm{c}}$ & $\mathrm{p}<0,0001$ \\
\hline FS-TS & $19,42 \pm 2,76$ & $13,06 \pm 2,30$ & $17,64 \pm 1,55$ & $\mathrm{p}=0,2023$ \\
\hline FM-TS & $4,66 \pm 0,01^{\mathrm{a}}$ & $0 \pm 1,16^{\mathrm{a}}$ & $18,94 \pm 5,08^{\mathrm{b}}$ & $\mathrm{p}=0,0060$ \\
\hline FS-PBMCs & $0 \pm 4,20^{\mathrm{a}}$ & $7,32 \pm 3,37^{\mathrm{b}}$ & $253,60 \pm 1,76^{\mathrm{c}}$ & $\mathrm{p}<0,0001$ \\
\hline FM-PBMCs & $47,88 \pm 10,66^{\mathrm{a}}$ & $19,32 \pm 4,89^{\mathrm{b}}$ & $16,44 \pm 0,21^{\mathrm{b}}$ & $\mathrm{p}=0,0306$ \\
\hline
\end{tabular}

Valores são média _EPM. Número de animais=3; valores de cada animal medidos em duplicata. Student-Newman-Keuls, p<0,05: Controle vs Artrítico vs Resistente para uma mesma amostra (letras diferentes na mesma linha indicam diferença significativa).

Comparando artríticos versus resistentes, evidenciam-se diferentes níveis do teor de LTB4 na FM do TS e na FS de PBMCs (maiores no AR) (Tabela 2), juntamente com níveis distintos de hidrólise de LT-A4 no SY, FM de TS e FS de PBMCs (maiores no RE) (Tabela 3).

A Tabela 4 mostra o resumo das alterações observadas nas atividades APB e LT-A4-H e nos níveis de LT-B4 em ratos artríticos e resistentes no modelo CIA em relação aos controles sadios. 
Tabela 4 - Sentido das alterações nos níveis de LT-B4 e de atividades de APB e LT-A4-H em ratos artríticos e resistentes no modelo CIA, relativamente aos controles sadios.

\begin{tabular}{|l|c|c|c|c|c|c|}
\hline \multirow{2}{*}{ Amostras } & \multicolumn{2}{|c|}{ LT-B4 } & \multicolumn{2}{c|}{ Atividade LT-A4-H } & \multicolumn{2}{c|}{ Atividade APB } \\
\cline { 2 - 7 } & Artrítico & Resistente & Artrítico & Resistente & Artrítico & Resistente \\
\hline PLASMA & $\uparrow$ & $\uparrow$ & $=$ & $=$ & $=$ & $\downarrow$ \\
\hline SY & $\uparrow$ & $\uparrow$ & $\uparrow$ & $\uparrow$ & $=$ & $\downarrow$ \\
\hline FS-TS & $\downarrow$ & $\downarrow$ & $=$ & $=$ & $\uparrow$ & $=$ \\
\hline FM-TS & $\uparrow$ & $\uparrow$ & $=$ & $\uparrow$ & $\uparrow$ & $=$ \\
\hline FS-PBMCs & $=$ & $\downarrow$ & $\uparrow$ & $\uparrow$ & $\downarrow$ & $\downarrow$ \\
\hline FM-PBMCs & $\downarrow$ & $\downarrow$ & $\downarrow$ & $\downarrow$ & $=$ & $\uparrow$ \\
\hline
\end{tabular}

Atividade LT-A4-H avaliada por EIA e atividade APB avaliada fluorimetricamente. (=) Sem diferença; $(\downarrow)$ diminuição; $(\uparrow)$ aumento.

\section{DISCUSSÃO}

Os resultados obtidos no presente estudo subsidiam a proposta do esquema da Figura 8, ilustrando um mecanismo de inter-relação hipotético entre os níveis de LT-B4 e das atividades de LT-A4-H e de APB em ratos artríticos e resistentes no modelo CIA, comparativamente a controles sadios. 
ARTRÍTICO

RESISTENTE

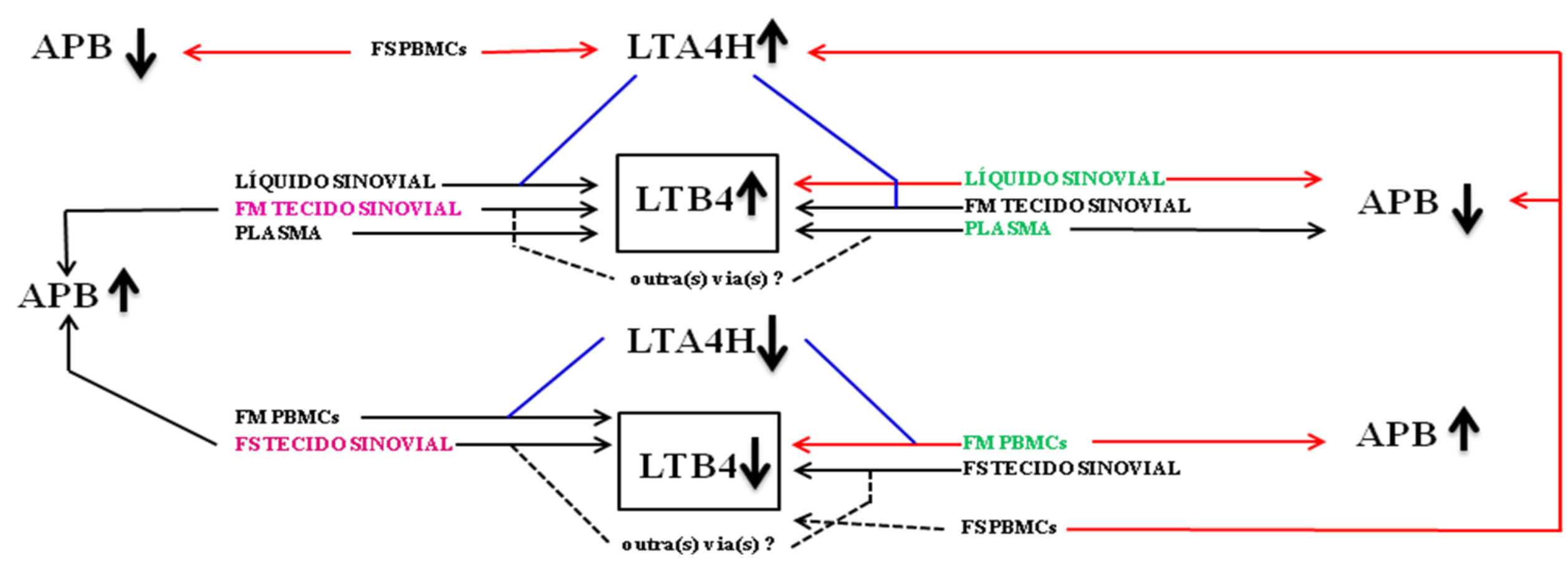

Figura 8 - Esquema ilustrativo dos resultados obtidos na presente dissertação, mostrando alterações nos níveis do conteúdo de LT-B4 e de atividades LT-A4-H e APB em ratos artríticos e resistentes à indução de artrite no modelo CIA. Setas $\uparrow$ e $\downarrow$ indicam, respectivamente, valores maiores ou menores em relação a ratos controles sadios. Linha contínua em azul indica situação em que a alteração no nível de LT-B4 relaciona-se positivamente com a alteração no nível de atividade LT-A4-H. Linha tracejada em preto indica situação em que a alteração no nível de LT-B4 não se relaciona positivamente com a alteração no nível de atividade LT-A4-H. Em lilás ou verde estão assinalados os materiais biológicos onde os níveis de atividade APB são, respectivamente, marcadores de artrite ou resistência. Notar que o sentido das alterações nos níveis do conteúdo de LT-B4 e de atividade LTA4-H (Tabela 4) na maioria dos materiais biológicos examinados não permite a distinção entre artríticos e resistentes, o que, no entanto, é evidenciado pelas diferenças quantitativas mostradas nas Tabelas 2 e 3. As linhas contínuas em vermelho destacam o fato de que em todas as situações e materiais em que ocorrem alterações concomitantes nos níveis de atividades LT-A4-H e APB, estas se relacionam inversamente. 


\subsection{Avaliação da indução da artrite no modelo CIA}

$\mathrm{O}$ aspecto inflamado do joelho vem sendo frequentemente utilizado como parâmetro de avaliação da presença de artrite (CUZZOCREA et al., 2005; TRENTHAM et al., 1977; WESTMAN et al., 2006). O presente estudo mostra que animais artríticos e resistentes no modelo CIA, no inicio do desenvolvimento da doença, podem ser distinguidos macroscopicamente de acordo com a presença de eritema e/ou cianose e inchaço grave que toma inteiramente ambas as patas traseiras (artríticos), bem como pela total ausência destes sinais (resistentes), condições também já confirmadas pelos aspectos histológicos correspondentes da articulação tíbio-tarsal de ratos submetidos a este mesmo modelo (YAMASAKI et al., 2012). Com base na escala de classificação macroscópica proposta por ERLANDSSON HARRIS et al. (1997), todos os animais artríticos selecionados no presente estudo obtiveram a pontuação máxima para as patas traseiras.

O aumento do título de AACII não é um indicativo diferencial da AR. Sabe-se que ocorre em outras doenças e que animais submetidos ao tratamento com CII heterólogo apresentam aumento deste título (ERLANDSSON HARRIS et al., 1997). Embora a transferência passiva de anticorpos contra CII tenha sido descrita como um modelo para induzir artrite semelhante à AR em roedores (NANDAKUMAR, 2010), não havia informação da ocorrência ou não de alteração no título de AACII em animais que não desenvolvessem inflamação típica da artrite no modelo CIA, tal qual agora mostrado no presente estudo. Segundo NANDAKUMAR (2010), a resposta de células B em modelos experimentais de CIA ocorre contra uma série de epítopos da tripla hélice de colágeno. A hipótese proposta é a de que o aumento do título de AACII em ratos imunizados com CII, que desenvolvem ou não inflamação, ocorre porque o colágeno, como uma molécula grande que conteria diferentes epítopos, seria imunorreativo em diferentes graus para diferentes anticorpos contra os seus diferentes epítopos, corroborando então a existência de anticorpos patogênicos e não patogênicos para o CII (NANDAKUMAR, 2010; MORGAN, 1990). Por outro lado, o alto título de AACII em animais resistentes à manifestação da artrite reforça a concepção de que o desencadeamento da doença é multifatorial.

$\mathrm{O}$ TNF- $\alpha$ é uma das principais citocinas pró-inflamatórias na AR, sendo encontrado em altas concentrações no soro e líquido sinovial de pacientes com esta doença (MCINNEES et al., 2011; SCOTT et al., 2010; DOAN \& MASSAROTTI, 2005). De fato, neste modelo experimental de AR os resultados do presente estudo mostram que a presença de TNF- $\alpha$ em 
níveis detectáveis ocorre somente nos animais tratados com CII e que desenvolvem edema artrítico.

\subsection{Avaliação do fracionamento do tecido sinovial e de PBMCs}

A atividade LDH é bem conhecida como um marcador citosólico (ALPONTI et al., 2011; OLIVO et al., 2008; ZAMBOTTI-VILLELA et al., 2007; MARINHO et al., 2006; OLIVO et al., 2005; GASPARELLO-CLEMENTE et al., 2003; ERLANDSSON HARRIS et $a l .$, 1997) e seu maior nível na FS, em comparação com FM, no tecido sinovial e PBMCs, reflete a eficiência do processo de fracionamento aqui utilizado. Assim, o presente estudo é o primeiro a detectar e analisar as atividades APB e LT-A4-H nessas frações separadas do tecido sinovial e de PBMCs.

\subsection{Atividade APB}

Apesar de ser considerada predominantemente citosólica, a APB foi encontrada associada à membrana no presente trabalho e em outros (FOULON et al., 1999; BALOGH et al., 1998) e também ao complexo de Golgi, onde parece chegar transitando do retículo endoplasmático (BALOGH et al., 1998). No entanto, não há descrição de domínios transmembranais na sua estrutura e uma hipótese é que interaja com um receptor de membrana (FOULON et al., 1999). Intracelularmente, a proteína EC 3.4.11.6 pode estar envolvida no processamento antigênico, por estar presente no proteassoma (HATTORI \& TSUJIMOTO, 2004). Os peptídeos gerados pela degradação do proteassoma são transportados para o retículo endoplasmático (HATTORI \& TSUJIMOTO, 2004) onde podem se ligar ao MHC II (LI et al., 2005). Além disso, muitos peptídeos do retículo endoplasmático sofrem clivagem do resíduo N-terminal (HATTORI \& TSUJIMOTO, 2004) e a APB poderia também atuar nesse compartimento, auxiliando no processamento antigênico. Por outro lado, a APB associada à membrana pode agir sobre peptídeos angiogênicos extracelulares como a calidina (BALOGH et al., 1998) e angiotensina (Ang) III gerando a Ang IV (RUIZ-ORTEGA et al., 2007). A formação de pannus, tanto na AR como na CIA, é dependente da angiogênese e tem sido cada vez mais reconhecido que peptídeos são parte do mecanismo que contribui para a inflamação autoimune na AR (KOFFEMAN et al., 2009). Por sua vez, o papel dos polimorfismos na 
suscetibilidade ao desenvolvimento de doenças é cada vez mais relevante para as perspectivas da prática médica atual (CRONSTEIN, 2010).

No presente estudo, foi encontrada atividade APB na fração de membrana do tecido sinovial e esta atividade também está presente na fração de membrana de PBMCs. Uma pergunta a ser feita é se a atividade APB encontrada no líquido sinovial e no plasma deriva do tecido sinovial e/ou PBMCs. Para outra aminopeptidase, a DPPIV, acredita-se que o mecanismo de desprendimento desta proteína da superfície da célula para o plasma é causado por enzimas do plasma (GORRELL et al., 2001).

Na fração solúvel de PBMCs houve decréscimo da atividade APB nos animais artríticos e resistentes. Os animais artríticos apresentaram aumento da APB nas frações solúvel e de membrana do tecido sinovial, o que poderia resultar na formação de Ang IV e agravar a inflamação no local afetado pela artrite, mostrando ser a atividade APB um marcador da artrite e que intracelularmente em PBMCs (na fração solúvel das células) esta atividade pode ser crucial no desencadeamento da doença. Além disso, destaca-se também o decréscimo da atividade APB do líquido sinovial e no plasma e o aumento desta atividade na fração de membrana de PBMCs como uma das peculiaridades dos animais resistentes à indução de artrite e que poderia refletir um mecanismo da resistência ao desenvolvimento da doença e com potenciais implicações prognósticas.

\subsection{Níveis de LT-B4 e atividade de LT-A4-H}

\subsubsection{Por que comparar as medidas de LT-B4 nas metodologias de HPLC e EIA?}

Até recentemente, a metodologia usual para a medida de LT-B4 era o HPLC, por permitir o uso de padrões (prostaglandinas B1 e B2) de tempo de retenção similar ao do LT-B4, mas de menor custo e labilidade. Atualmente, há a disponibilidade comercial do LT-B4 a preços mais acessíveis e a possibilidade de seu manuseio mais rigoroso, além do desenvolvimento de kits imunoenzimáticos para sua medida direta. Daí, no presente estudo, a comparação entre ambas as metodologias pretendeu adicionar informações importantes sobre a qualidade e adequação das medidas de LT-B4 proporcionadas por estas metodologias em amostras obtidas sob diferentes circunstâncias fisiopatológicas e de manuseio. 


\subsubsection{Níveis de LT-B4 medidos pela área do pico obtido em HPLC}

A medida de LT-B4 por HPLC, baseada no método de RUDBERG et al (2002), foi aprimorada metodologicamente no presente estudo tendo sido adaptada, simplificada e convalidada.

\subsubsection{Níveis de LT-B4 medidos por EIA diretamente em material bruto}

Observou-se que a quantificação de LT-B4 por esta metodologia propicia valores com elevado grau de correlação com os obtidos pela medida da área do pico obtido da cromatografia em HPLC. Comparativamente ao HPLC, a metodologia EIA, além de também apresentar alta especificidade, dispensa etapas de limpeza (remoção de substâncias interferentes), assim encurtando o tempo e simplificando a análise. Outras vantagens relativas desta metodologia são o menor custo, uso de pequenas quantidades de amostra e facilidade de realizar os procedimentos. Um único inconveniente é que o kit de EIA tem uma vida útil limitada. Assim, comparando os valores de LT-B4 obtidos em cada uma das metodologias usadas, observa-se que os valores do EIA resultaram em diferenças estatísticas mais consistentes entre os grupos que os obtidos por HPLC, o que pode ser atribuído aos procedimentos inerentes ao HPLC (extração em coluna Sep-Pak para minimizar impurezas e secagem, por exemplo). Consequentemente, no presente estudo apenas os valores de LT-B4 obtidos por EIA foram usados nas comparações dos níveis deste leucotrieno e da atividade LT-A4-H entre os grupos animais e com a atividade APB.

8.4.4. Comparação dos níveis de LT-B4 obtidos por EIA do pico de HPLC versus EIA das amostras brutas

Os picos do HPLC de LT-B4 padrão ou das amostras contendo LT-B4 quando coletados e aplicados no EIA não se correlacionam quanto aos valores medidos de LT-B4 por EIA ou medidos por área do pico do HPLC. Mais uma vez, o processo que estas amostras sofrem no procedimento de HPLC antes da aplicação no EIA mostrou-se capaz de alterar a integridade imunogênica do LT-B4.

\subsubsection{Significado da medida de LT-B4 em amostras sem incubar e incubadas com LT-A4}

No presente estudo foi medido LT-B4 endógeno pré-existente ex vivo nas amostras sob estudo e nestas mesmas amostras após incubação in vitro com LT-A4. Neste último caso, o teor de LT-B4 pré-existente soma-se ao formado sob a ação hidrolítica de LT-A4-H eventualmente presente em tais amostras. Portanto, a subtração do teor de LT-B4 pré- 
existente daquele obtido após incubação com LT-A4 foi utilizada para estimar a atividade LTA4-H das amostras. Surpreendentemente, neste estudo, por este método, a atividade LT-A4-H foi encontrada na fração de membrana do tecido sinovial e de PBMCs. Pelo nosso conhecimento, como só há um relato anterior (em hepatócitos) sobre atividade LT-A4-H ligada à membrana (GUT et al., 1987), a confirmação e o significado fisiopatológico deste achado requer aprofundamento, em especial uma avaliação por immunoblot. Quanto a possíveis especulações sobre este achado, embora a 5-LO tenha sido inicialmente purificada como uma proteína citosólica, atualmente sabe-se que se trata de enzima translocada para o envelope nuclear (BROCK et al., 1997; BROCK et al., 1995) e para corpos lipídicos de eosinófilos, após estimulação (BOZZA et al., 1997). Fosfolipase A2 citosólica (cPLA2) também é translocada para o envelope nuclear (HIRABAYASHI et al., 1999), e COX-1 e COX-2 também estão presentes na membrana nuclear, de modo que, atualmente, é correntemente aceito que a membrana nuclear é o principal local de produção dos eicosanóides. Sabe-se, também, que embora a 5-LO tenha uma expressão limitada a células B, macrófagos, monócitos, mastócitos, neutrófilos, neurônios, eosinófilos e células dendríticas (YOKOMIZO et al., 2001; HEDI et al., 2004), todas as células são fontes potenciais de produção de LT-B4, porque a LT-A4-H é expressa de forma ubíqua e o excesso de LT-A4 gerado pelas células que expressam 5-LO pode difundir-se para células vizinhas que não possuem significativa atividade 5-LO e que, portanto, não possuem também a capacidade de gerar o substrato LT-A4 (YOKOMIZO et al., 2001; HAEGGSTRÖM et al., 2000), mas que possuem LT-A4-H para efetuarem sua conversão em LT-B4, num mecanismo conhecido como biossíntese transcelular (WERZ, 2002). Os neutrófilos, monócitos, linfócitos e hemácias são ricas fontes de LT-A4-H. Em contraste, os eosinófilos têm baixos níveis, enquanto basófilos e plaquetas parecem ser praticamente desprovidos da enzima (HAEGGSTRÖM et al., 2000). O mecanismo molecular e os domínios de 5-LO necessários para a translocação têm sido intensivamente estudados (YOKOMIZO et al., 2001). Em contraste com a 5-LO, há informações limitadas sobre a ativação e eventual translocação de LT-A4-H. Acredita-se que o LT-B4 seja produzido em condições normais principalmente pelos leucócitos. Na inflamação, no entanto, a produção de LT-B4 é incrementada tanto em leucócitos quanto em outras células (YOKOMIZO et al., 2001; HAEGGSTRÖM et al., 2000), o que tem sido explicado pela biossíntese transcelular (CHEN et al., 2010; YOKOMIZO et al., 2001; HAEGGSTRÖM et al., 2000; SALA et al., 1996; SAMUELSSON et al., 1989). Essa biossíntese transcelular pode ser considerada um fenômeno promovido por interações célula-célula e que já foi demonstrado in vitro na formação de leucotrienos em 
monócitos e linfócitos (JAKOBSSON et al., 1991) e entre neutrófilos e células endoteliais, eritrócitos, plaquetas e lavado do fluido broncoalveolar humano (IVERSEN et al., 1995; MUNAFO et al., 1994; CLAESSON et al., 1988; MACLOUF et al., 1988).

\subsection{Expressão gênica de APB (EC 3.4.11.6) e de LT-A4-H (EC 3.3.2.6)}

A existência dos genes para as proteínas EC 3.3.2.6 e EC 3.4.11.6 foi confirmada no tecido sinovial de ratos controles sadios. O tecido sinovial e o líquido sinovial retirados dos animais sob estudo contêm, em algum grau, infiltrados leucocitários. Portanto, o conteúdo total de ambas as enzimas no plasma, líquido sinovial e tecido sinovial deve ser ao menos parcialmente derivado destas células, em especial nos animais artríticos.

\subsection{Correlações entre os níveis de LT-B4 e as atividades LT-A4-H e APB e seu possível significado na funcionalidade das proteínas responsáveis por estas atividades e na resistência e no desenvolvimento de artrite no modelo CIA}

O sentido das alterações nas medidas de hidrólise de LT-A4 e dos níveis de LT-B4 entre

artríticos versus resistentes, comparativamente aos controles, relaciona-se positiva e paralelamente em todos os compartimentos sob estudo, exceto na fração de membrana do tecido sinovial e na fração solúvel de PBMCs, evidenciando essas medidas como fatores diferenciais dessas duas condições em relação à condição saudável. Por sua vez, constatou-se que também há diferenças quantitativas entre artríticos versus resistentes quanto aos níveis de hidrólise de LT-A4 e de teor de LTB4 o que distingue essas duas situações. Por outro lado, como sumarizado na Tabela 4, comparando as alterações de hidrólise de LT-A4 versus conteúdo de LT-B4 em relação aos controles, nota-se que no líquido sinovial e na fração de membrana de PBMCs dos artríticos e resistentes e na fração de membrana do tecido sinovial dos resistentes essas alterações ocorrem no mesmo sentido, o que confirma nestes casos o papel primordial desempenhado pelas alterações da LT-A4-H na biossíntese de LT-B4. No entanto, no plasma, na fração solúvel do tecido sinovial e de PBMCs de artríticos e resistentes e na fração de membrana do tecido sinovial de artríticos não há qualquer correlação entre LTB4 e LT-A4-H, indicando que as alterações na formação de LT-B4 nestes casos envolveriam outros passos da biossíntese e degradação do LT-B4 que não o da atividade LT-A4-H. O 
próprio teor de LT-B4 não apresenta um sentido único de alteração em todos os materiais biológicos examinados nos artríticos e resistentes em relação aos controles sadios, ou seja, as alterações dos níveis de LT-B4 podem ter sentidos distintos de acordo com o compartimento biológico em que se realizam as medidas. Comparando artríticos e resistentes, nos compartimentos onde há diferenças entre ambos são observados maiores teores de LT-B4 em artríticos e de hidrólise de LT-A4 nos resistentes. Esse achado é coerente no que se refere ao aumento de LT-B4 (pró-inflamatório) nos artríticos, mas à primeira vista parece paradoxal no que se refere aos resistentes, considerando que a maior hidrólise de LT-A4 deveria levar a um maior teor de LT-B4 nestes animais, comparativamente aos artríticos. O aumento do LT-B4 nos artríticos deve contribuir para a cronicidade da inflamação e ocorre justamente na fração de membrana do tecido sinovial e na fração solúvel dos PBMCs, alvos importantes da doença. Nos resistentes a atividade LT-A4-H está aumentada nos mesmos compartimentos e também no líquido sinovial, enquanto a atividade APB está diminuída na fração solúvel dos PBMCs e no líquido sinovial e inalterada na fração de membrana do tecido sinovial, o que é sugestivo de que a formação de LT-B4 esteja inversamente correlacionada com a atividade APB e que o papel desta última atividade (cujo aumento induz aumento da angiogênese, por exemplo), em relação ao da formação de LT-B4, seja comparativamente mais decisivo no desenvolvimento da artrite. Por sua vez, a comparação das atividades LT-A4-H e APB entre artríticos e resistentes revela que no plasma de animais resistentes e nas frações solúvel e de membrana do tecido sinovial dos artríticos, as alterações observadas na atividade APB não implicam em qualquer alteração na atividade LT-A4-H. Por outro lado, no líquido sinovial dos artríticos e na fração de membrana do tecido sinovial e de PBMCs dos resistentes as alterações observadas na atividade LT-A4-H não implicam em qualquer alteração na atividade APB. Tais constatações sugerem a existência de modulação diferencial da especificidade/eficiência/afinidade catalítica de cada uma destas enzimas sobre os substratos epóxi e peptídico, ou que atuem independentemente com uma única ação catalítica nestes materiais biológicos. Porém, nas situações em que concomitantemente ocorrem alterações da APB e da LT-A4-H, tais alterações relacionam-se eminentemente de modo inverso, corroborando o padrão de bifuncionalidade correntemente descrito tanto para a proteína APB (EC 3.4.11.6) (PHAM et al., 2007; PIESSE et al., 2004; CADEL et al., 1997) quanto para a proteína LT-A4-H (EC 3.3.2.6) (DE OLIVEIRA et al., 2011; HAEGGSTRÖM et al., 2000; FOULON et al., 1999; CADEL et al., 1997). Uma análise estrutural da APB e da LT-A4-H mostrou que diferenças na distribuição de potencial eletrostático entre APB e LT-A4-H podem refletir interações diferentes entre proteína-proteína e entre a proteína e o meio em que 
esta está inserida, sendo que a APB apresenta mais partes hidrofóbicas do que a LT-A4-H (PHAM et al., 2007). A diferença entre os potenciais negativos eletrostáticos no sítio catalítico poderia explicar a diferença de especificidade enzimática e entre os seus respectivos substratos (PHAM et al., 2007), implicando na possibilidade de que uma ação catalítica não interfira na outra. Ainda, FUKASAWA et al (1999) defende a ausência de atividade epóxihidrolase na APB de ratos e humanos, sugerindo que, apesar da grande semelhança estrutural entre as proteínas APB e a LT-A4-H, a APB parece ter evoluído como uma enzima funcional diferente da LT-A4-H.

Quanto ao envolvimento da APB na AR, como já mencionado, poderia ser hipotetizado que estaria relacionado com a angiogênese, pois a calidina (HEFFELFINGER, 2007; BALOGH et al., 1998) e Ang III (RUIZ-ORTEGA et al., 2007), substratos da APB, têm reconhecidas ações na regulação da angiogênese (HEFFELFINGER, 2007). Também se cogita que a APB, ao hidrolisar o quimioatraente de neutrófilos Pro-Gly-Pro (PGP), facilitaria a resolução da inflamação, mas que esta ação também poderia levar ao acúmulo de PGP e neutrófilos (SNELGROVE et al., 2010). No entanto, ainda é prematuro definir um possível papel da APB na AR. No caso da LT-A4-H o envolvimento com a AR parece mesmo relacionar-se com o LT-B4. HASHIMOTO et al (2003) quantificaram a expressão gênica dos receptores de LT-B4, BLT1 e BLT2, por RT-PCR e hibridização in situ, em tecidos sinoviais de pacientes artríticos, mostrando forte expressão de ambos neste tecido inflamado. MATHIS et al (2010) mostraram uma redução da incidência e gravidade da doença, incluindo a proteção contra a perda óssea e da cartilagem, em ratos nocauteados para os receptor BLT2 em modelo de artrite induzida por auto-anticorpos. Maiores níveis de LT-B4 foram encontrados no plasma na fase ativa da $\mathrm{AR}$, quando comparado com a fase inativa e indivíduos sadios (XU, 2010). Porém, paradoxalmente, o presente estudo constatou que em alguns compartimentos (fração solúvel do tecido sinovial, fração solúvel de PBMCs só nos resistentes e fração de membrana de PBMCs) o nível de LT-B4 em artríticos e resistentes, ao invés de maior, como nos demais materiais aqui estudados, é relativamente menor que nos controles sadios. Este menor nível de LT-B4 na fração solúvel do tecido sinovial nos animais artríticos e resistentes em relação aos controles pode ser relacionado com o aumento concomitante deste nível na fração de membrana do tecido sinovial, sugerindo translocação do citosol para a membrana em resposta à reação inflamatória. Uma possível difusão de LTB4 para outras células e/ou compartimentos durante o processo inflamatório por sua vez poderia explicar o menor nível deste leucotrieno na fração de membrana de PBMCs dos artríticos e resistentes e na fração solúvel de PBMCs dos resistentes. 
Em suma, apesar de seu significado na artrite reumatoide ser ainda pouco conhecido, em certos compartimentos aqui estudados a atividade APB destaca-se como marcadora da resistência e da suscetibilidade ao desenvolvimento de artrite no modelo CIA, característica que também foi constatada para a atividade LT-A4-H e para o conteúdo de LT-B4. As enzimas com atividades APB e LT-A4-H podem exibir cada qual somente uma única dessas atividades catalíticas modulada independentemente, ou ambas as atividades moduladas inversamente sob as situações de artrite e resistência.

\section{CONCLUSÕES}

O presente estudo mostra que:

1. Níveis elevados de TNF- $\alpha$, sem alteração nos títulos de AACII e, obviamente, a presença de edema, eritema e cianose caracterizam a presença de artrite no rato submetido ao modelo CIA;

2. LT-A4-H (EC 3.3.2.6) e APB (EC 3.4.11.6) têm expressão gênica no tecido sinovial em animais controles sadios;

3. A atividade APB, o conteúdo de LT-B4 e a atividade LT-A4-H são detectáveis na FS e FM do tecido sinovial e de PBMCs, e no líquido sinovial e plasma de todos os grupos estudados;

4. Considerando custo, praticidade e confiabilidade, a medida do teor de LT-B4 pelo EIA é a mais adequada, comparativamente ao HPLC;

5. Os níveis de LT-B4 medidos após incubação in vitro com LT-A4 (substrato) e amostra biológica, após a exclusão dos níveis endógenos de LT-B4 (já formado), mostrou-se uma estratégia eficiente para medida da atividade de LT-A4-H in vitro de tais amostras;

6. A atividade APB é marcadora do desenvolvimento da artrite (aumento da APB na FS e FM do tecido sinovial) e da resistência ao desenvolvimento da doença (decréscimo da atividade APB no líquido sinovial e no plasma e aumento na FM de PBMCs) no modelo CIA. 
7. Em geral, o sentido das alterações no teor de LT-B4 e na atividade LT-A4-H em relação aos controles é indistinguível entre artríticos e resistentes no modelo CIA, mas quantitativamente tais alterações, compartimento-dependentes, distinguem marcadamente estes dois grupos entre si. Estas características podem ser úteis tanto para subsidiar futuros estudos explorando uma possível utilidade diagnóstica da medida do teor de LT-B4 e da atividade LT-A4-H, como para explorar o papel das diferenças quantitativas de ambas no desenvolvimento ou resistência à artrite;

8. Comparativamente aos controles, alterações nos níveis de LT-B4 podem ser relacionadas diretamente com alterações na atividade LT-A4-H apenas no líquido sinovial e FM de PBMCs de animais artríticos e resistentes e na FM do tecido sinovial dos resistentes, mostrando que a regulação dos níveis de LT-B4 nem sempre depende da atividade de LT-A4$\mathrm{H}$;

9. LT-A4-H e APB apresentam modulação diferencial de especificidade / eficiência / afinidade catalíticas sobre os substratos epóxi e peptídico, ou atuam independentemente com uma única ação catalítica em certos compartimentos. Porém, nas situações em que alterações em ambas as atividades catalíticas ocorrem concomitantemente, tais atividades relacionam-se inversamente, sugerindo interação ou bifuncionalidade dependente de inibição concorrente de uma delas. 


\section{REFERÊNCIAS BIBLIOGRÁFICAS}

ALPONTI, R. F.; FREZZATTI, R.; BARONE, J. M.; ALEGRE, V. D.; SILVEIRA, P. F. Dipeptidyl peptidase IV in the hypothalamus and hippocampus of monosodium glutamate obese and food deprived rats. Metabolism. 2011;60:234-242.

ANDERSON, G. D.; KEYS, K. L.; DE CIECHI, P. A.; MASFERRER, J. L. Combination therapies that inhibit cyclooxygenase-2 and leukotriene synthesis prevent disease in murine collagen induced arthritis. Inflamm Res. 2009;58:109-117.

BALOGH, A.; FOULON, T.; PICART, R.; DER GARABEDIAN, A.; ROUSSELET, A.; TOUGARD, C.; COHEN, P. Aminopeptidase B: a processing enzyme secreted and associated with the plasma membrane of rat pheochromocytoma (PC12) cells. J Cell Sci. 1998;111:161169.

BERGMEYER, H. U.; BRENT, E. Methods in enzymatic analysis. London: Academic Press. 1972; v. 2.

BRADFORD, M.M. A rapid and sensitive method for the quantitation of microgram quantities of protein utilizing the principle of protein-dye binding. Anal Biochem. 1976;72:248-254.

BRAND, D. D.; KANG, A. H.; ROSLONIEC, E. F. Immunopathogenesis of Collagen Arthritis. Springer Semin Immunopathology. 2003;25:3-18.

BROCK, T. G.; MCNISH, R. W.; PETERS-GOLDEN, M. Translocation and leukotriene synthetic capacity of nuclear 5-lipoxygenase in rat basophilic leukemia cells and alveolar macrophages. J Biol Chem. 1995;270:21652-21658.

BROCK, T. G.; MCNISH, R. W.; BAILIE, M. B.; PETERS-GOLDEN, M. Rapid import of cytosolic 5-lipoxygenase into the nucleus of neutrophils after in vivo recruitment and in vitro adherence. J Biol Chem. 1997;272:8276-8280.

BOZZA, P. T.; YU, W.; PENROSE, J. F.; MORGAN, E. S.; DVORAK, A. M.; WELLER, P. F. Eosinophil lipid bodies: specific, inducible intracellular sites for enhanced eicosanoid formation. J Exp Med. 1997; 186:909-920.

CADEL, S.; FOULON, T.; VIRON, A.; BALOGH, A.; MIDOL-MONNET, S.; NOEL, N.; COHEN, P. Aminopeptidase B from the rat testis is a bifunctional enzyme structurally related to leukotriene-A4 hydrolase. Natl Acad Sci Proc USA. 1997;94:2963-2968.

CAO, Y.; BROMBACHER, F.; TUNYOGI-CSAPO, M.; GLANT, T. T.; FINNEGAN, A. Interleukin-4 regulates proteoglycan-induced arthritis by specifically suppressing the innate immune response. Arthritis Rheumatoid. 2007;56:861-870.

CHEN, M.; LAM, B. K.; LUSTER, A. D.; ZARINI, S.; MURPHY, R. C.; BAIR, A. M.; SOBERMAN, R. J.; LEE, D. M. Joint Tissues Amplify Inflammation and Alter Their 
Invasive Behavior via Leukotriene B4 in Experimental Inflammatory Arthritis. J Immunol. 2010;185:5503-5511.

CLAESSON, H. E.; HAEGGSTRÖM, J. Human endothelial cells stimulate leukotriene synthesis and convert granulocyte released leukotriene A4 into leukotrienes B4, C4, D4 and E4. Eur J Biochem. 1988;173:93-100.

CREMER, M. A.; ROSLONIEC, E. F.; KANG, A. H. The cartilage collagens: a review of their structure, organization, and role in the pathogenesis of experimental arthritis in animals and in human rheumatic disease. Journal Mol Med. 1998;76:275-288.

CRONSTEIN, B. N. A personal journey from the joint to the heart. Arthritis Res Ther. 2010;12:134.

CUZZOCREA, S.; MAZZON, E.; DI PAOLA, R.; GENOVESE, T.; MUIÀ, C.; CAPUTI, A.P.; SALVEMINI, D. Synergistic interaction between methotrexate and a superoxide dismutase mimetic: pharmacologic and potential clinical significance. Arthritis Rheum. 2005;52:3755-3760.

DE OLIVEIRA, E. O.; WANGA, K.; KONG, H.; KIM, S.; MIESSAU, M.; SNELGROVEl, R. J.; SHIM, Y. M.; PAIGEET, M. Effect of the leukotriene A4 hydrolase aminopeptidase augmentor 4-methoxydiphenylmethane in a pre-clinical model of pulmonary emphysema. Medicinal Chemistry Letters. 2011;21:6746-6750.

DOAN, T.; MASSAROTTI, E. Rheumatoid arthritis: an overview of new and emerging therapies. J. Clin Pharmacology. 2005;45:751-762.

ERLANDSSON HARRIS, M.; LILJESTROM, M.; KLARESKOG, L. Characterization of synovial fluid effusion in collagen-induced arthritis (CIA) in the DA rat; a comparison of histology and antibody reactivities in an experimental chronic arthritis model and rheumatoid arthritis (RA). Clin Exp Immunol. 1997;107:480-484.

FITZPATRICK, F. A.; LEPLEY, R.; ORNING, L.; DUFFIN, K. Suicide inactivation of leukotriene A4 hydrolase/aminopeptidase. Ann N Y Acad Sci. 1994;744:31-38.

FORD-HUTCHINSON, A. W. Leukotriene B4 in inflammation. Crit Rev Immunol. 1990;10:1-12.

FOULON, T.; CADEL, S.; COHEN, P. Aminopeptidase B (EC 3.4.11.6). Int J Biochem Cell Biol. 1999;31:747-750.

FUKASAWA, K. M.; FUKASAWA, K.; HARADA, M.; HIROSE, J.; IZUMI, T.; SHIMIZU, T. Aminopeptidase B is structurally related to leukotriene-A4 hydrolase but is not a bifunctional enzyme with epoxide hydrolase activity. Biochem J. 1999;339:497-502.

GASPARELLO-CLEMENTE, E.; CASIS, L.; VARONA, A.; GIL, J.; IRAZUSTA, J.; SILVEIRA, P.F.; Aminopeptidases in visceral organs during alterations in body fluid volume and osmolality. Peptides. 2003;24:1367-1372. 
GORRELL, M. D.; GYSBERS, V.; MCCAUGHAN, G. W. CD26: a multifunctional Integral membrane and secreted protein of activated lymphocytes. Scand J Immunol. 2001;54:249 264.

GRAGE-GRIEBENOW, E.; BARAN, J.; LOPPNOW, H.; LOSS, M.; ERNST, M.; HAD, H.; PRYJMA, J. An Fcy receptor I (CD64)- negative subpopulation of human peripheral blood monocytes is resistant to killing by antigen-activated CD4-positive cytotoxic T cells. Eur J Immunol. 1997;27:2358-2365.

GRICE, C. A.; TAYS, K. L.; SAVALL, B. M.; WEI, J.; BUTLER, C. R.; AXE, F. U.; BEMBENEK, S. D.; FOURIE, A. M.; DUNFORD, P. J.; LUNDEEN, K.; COLES, F.; XUE, X.; RILEY, J. P.; WILLIAMS, K. N.; KARLSSON, L.; EDWARDS, J. P. Identification of a Potent, Selective, and Orally Active Leukotriene A4 Hydrolase Inhibitor with AntiInflammatory Activity. J Med Chem. 2008;51:4150-4169.

GRIFFITHS, M. M. Immunogenetics of collagen-induced arthritis in rats. Int Rev Immunology. 1988;4:1-15.

GUT, J.; GOLDMAN, D. W.; JAMIESON, G. C.; TRUDELL, J. R. Conversion of leukotriene A4 to leukotriene B4: catalysis by human liver microsomes under anaerobic conditions. Arch Biochem Biophys. 1987;259:497-509.

HAEGGSTRÖM, J. Z.; WETTERHOLM, A. Enzymes and receptors in the leukotriene cascade. Cell Mol Life Sci. 2002;59:742-753.

HAEGGSTRÖM, J. Z. Structure, Function, and Regulation of Leukotriene A4 Hydrolase. Am J Respir Crit Care Med. 2000;161:S25-31.

HASHIMOTO, A.; ENDO, H.; HAYASHI, I.; MURAKAMI, Y.; KITASATO, H.; KONO, S.; MATSUI, T.; TANAKA, S.; NISHIMURA, A.; URABE, K.; ITOMAN, M.; KONDO, H. Differential Expression of Leukotriene B4 Receptor Subtypes (BLT1 and BLT2) in Human Synovial Tissues and Synovial Fluid Leukocytes of Patients with Rheumatoid Arthritis. J Rheumatol. 2003;30:1712-1718.

HATTORI, A.; TSUJIMOTO, M. Processing of antigenic peptides by aminopeptidases. Biol Pharm Bull. 2004;27:777-780.

HEDI, H.; NORBERT, G. 5-Lipoxygenase Pathway, Dendritic Cells, and Adaptive Immunity. J Biomed Biotechnol. 2004;2004:99-105.

HEFFELFINGER, S. C. The renin angiotensin system in the regulation of angiogenesis. Curr Pharm Des. 2007;13:1215-1229.

HIETALA, M.A.; NANDAKUMAR, K. S.; PERSSON, L.; FAHLÉN, S.; HOLMDAHL, R.; PEKNA, M. Complement activation by both classical and alternative pathways is critical for the effector phase of arthritis. Eur J Immunology. 2004;34:1208-1216.

HIRABAYASHI, T.; KUME, K.; HIROSE, K.; YOKOMIZO, T.; IINO, M.; ITOH, H.; SHIMIZU, T. Critical duration of intracellular $\mathrm{Ca} 2+$ response required for continuous 
translocation and activation of cytosolic phospholipase A2. J Biol Chem. 1999;274:51635169.

HOLMDAHL, R.; LORENTZEN, J. C.; LU, S.; OLOFSSON, P.; WESTER, L.; HOLMBERG, J.; PETTERSSON, U. Arthritis induced in rats with nonimmunogenic adjuvants as models for rheumatoid arthritis. Immunol Rev. 2001;184:184-202.

HUI, M.; HUI, K. S. A novel aminopeptidase with highest preference for lysine. Neurochemical Research. 2006;31:95-102.

HWANGA, S.; HOOKA, V. Zinc Regulation of Aminopeptidase B Involved in Neuropeptide Production. FEBS Letters. 2008;582:2527-2531

IVERSEN, L.; KRISTENSEN, P.; NISSEN, J. B.; MERRICK, W. C.; KRAGBALLE, K. Purification and characterization of leukotriene A 4 hydrolase from human epidermis. FEBS Letters. 1995;358:316-322.

JAKOBSSON, P. J.; ODLANDER, B.; CLAESSON, H. E. Effects of monocyte-lymhocyte interaction on the synthesis of leukotriene B4. Eur J Biochem. 1991;196:395-400.

KIM, H.; BANG, J.; CHANG, H. W.; KIM, J. Y.; PARK, K. U.; KIM, S.; LEE, K.; CHO, C.; HWANG, I.; PARK, S. D.; HA, E.; JUNG, S. Anti-inflammatory effect of quetiapine on collagen-induced arthritis of mouse. Eur J Pharmacol. 2012;678:55-60.

KOBAYASHI, S.; MOMOHARA, S.; KAMATANI, N.; OKAMOTO, H. Molecular aspects of rheumatoid arthritis: role of environmental factors. FEBS J. 2008;275:4456-4462.

KOFFEMAN, E. C.; GENOVESE, M.; AMOX, D.; KEOGH, E.; SANTANA, E.; MATTESON, E. L.; KAVANAUGH, A.; MOLITOR, J. A.; SCHIFF, M. H.; POSEVER, J. O.; BATHON, J. M.; KIVITZ, A. J.; SAMODAL, R.; BELARDI, F.; DENNEHEY, C.; VAN DEN BROEK, T.; VAN WIJK, F.; ZHANG, X.; ZIESENISS, P.; LE, .; PRAKKEN, B. A.; CUTTER, G. C.; ALBANI, S. Epitope-specific immunotherapy of rheumatoid arthritis: clinical responsiveness occurs with immune deviation and relies on the expression of a cluster of molecules associated with $\mathrm{T}$ cell tolerance in a double-blind, placebo-controlled, pilot phase II trial. Arthritis Rheum. 2009;60:3207-3216.

LEE, M. H. \& MURPHY, G. What are the roles of metalloproteinases in cartilage and bone damage? Ann Rheum Dis. 2005;64:iv44-iv47.

LIANG, A. M.; CLARET, E.; OULED-DIAF, J.; JEAN, A.; VOGEL, D.; LIGHT, D. R.; JONES, S. W.; GUILFORD, W. J.; PARKINSON, J. F.; SNIDER, R. M. Development of a homogeneous time-resolved fluorescence leukotriene B4 assay for determining the activity of leukotriene A4 hydrolase. J Biomol Screening. 2007;12:536-544.

MACLOUF, J. A.; MURPHY, R. C. Transcellular metabolism of neutrophil-derived leukotriene A4 by human platelets. A potential cellular source of leukotriene C4. J Biol Chem. 1988;263:174-181. 
MANTLE, D.; FALKOUS, G.; WALKER, D. Quantification of protease activities in synovial fluid from rheumatoid and osteoarthritis cases: comparison with antioxidant and free radical damage markers. Clin Chim Acta. 1999;284:45-58.

MARINHO, C.E.; OLIVO, R.A.; ZAMBOTTI-VILLELA, L.; RIBEIRO-DE-ANDRADE, T. N.; FERNANDES, C.M.; SILVEIRA, P.F. Renal and macrophage aminopeptidase activities in cyclosporin-treated mice. Int Immunopharmacol. 2006;6:415-425.

MATHIS, S. P.; JALA, V. R.; LEE, D. M.; HARIBABU, B. Nonredundant Roles for Leukotriene B4 Receptors BLT1 and BLT2 in Inflammatory Arthritis. J Immunol. 2010;185:3049-3056.

MCINNES, I. B.; SCHETT, G. The pathogenesis of rheumatoid arthritis. N Engl J Med. 2011;365:2205-2219.

MORGAN, K. What do anti-collagen antibodies mean? Ann Rheum Dis. 1990;49:62-65.

MUNAFO, D. A.; SHINDO, K.; BAKER, J. R.; BIGBY, T. D. Leukotriene A4 hydrolase in human bronchoalveolar lavage fluid. J Clin Invest. 1994;93:1042-1050.

MYERS, L.K.; ROSLONIEC, E. F.; CREMER, M. A.; KANG, A. H. Collagen-Induced arthritis, an animal model of autoimmunity. Life Science. 1997;61:1861-1878.

NAKAMURA, R.M. Progress in the use of biochemical and biological markers for evaluation of rheumatoid arthritis. J Clin Lab Analyses. 2000;14:305-313.

NANDAKUMAR, K. S. Pathogenic antibody recognition of cartilage. Cell Tissue Res. 2010;339:213-220.

OKAMOTO, H.; KIIRE, A.; YAMANAKA, H.; KAMATANI, N. Molecular Targets of Rheumatoid Arthritis. Inflammation \& Allergy - Drug Targets. 2008;7:53-66.

OLIVO, R. A.; NASCIMENTO, N. G.; TEIXEIRA, C. F.; SILVEIRA, P. F.; Methotrexate and cyclosporine treatments modify the activities of dipeptidyl peptidase IV and prolyl oligopeptidase in murine macrophages. Clin Dev Immunol.2008; ID:794050.

OLIVO, R. A.; TEIXEIRA, C. F.; SILVEIRA, P. F. Representative aminopeptidases and prolyl endopeptidase from murine macrophages: comparative activity levels in resident and elicited cells. Biochem Pharmacol. 2005;69:1441-1450.

PANAYI, G. S. B cells: a fundamental role in the pathogenesis of rheumatoid arthritis? Rheumatology. 2005;44 Suppl 2:ii3-ii7.

PENNING, T. D.; RUSSELL, M. A.; CHEN, B. B.; CHEN, H. Y.; LIANG, C. D.; MAHONEY, M. W.; MALECHA, J. W.; MIYASHIRO, J. M.; YU, S. S.; ASKONAS, L. J.; GIERSE, J. K.; HARDING, E. I.; HIGHKIN, M. K.; KACHUR, J. F.; KIM, S. H.; VILLANIPRICE, D.; PYLA, E. Y.; GHOREISHI-HAACK, N. S.; SMITH, W. G. Synthesis of potent leukotriene A(4) hydrolase inhibitors. Identification of 3-[methyl[3-[4(phenylmethyl)phenoxy]propyl]amino] propanoic acid. J Med Chem. 2002;45:3482-3490. 
PFAFFL, M. W. A new mathematical model for relative quantification in real-time RT-PCR. Nucleic Acids Research. 2001;29:e45.

PHAM, V.; CADEL, M.; GOUZY-DARMON, C.; HANQUEZ, C.; BEINFELD, M. C.; NICOLAS, P.; ETCHEBEST, C.; FOULON, T. Aminopeptidase B, a glucagon-processing enzyme: site directed mutagenesis of the $\mathrm{Zn} 2+$-binding motif and molecular modeling. BMC Biochemistry. 2007;8:21.

PIESSE, C.; CADEL, S.; GOUZY-DARMONA, C.; JEANNY, J.; CARRIÈRE, V.; GOIDIN, D.; JONET, L.; GOURDJI, D.; COHENA, P.; FOULON, T. Expression of aminopeptidase B in the developing and adult rat retina. Experimental Eye Research. 2004;79:639-648.

RAWLINGS, N.D.; BARRETT, A. J.; WOESSNER, J. F. Handbook of proteolytic enzymes. Academic Press. 1998;1022-1029.

ROSENZWEIG, H. L.; JANN, M. M.; GLANT, T. T.; MARTIN, T. M.; PLANCK, S. R.; VAN EDEN, W.; VAN KOOTEN, P. J.; FLAVELL, R. A.; KOBAYASHI, K. S.; ROSENBAUM, J. T.; DAVEY, M. P. Activation of nucleotide oligomerization domain 2 exacerbates a murine model of proteoglycan-induced arthritis. J Leukoc Biol. 2009;85:711718.

RUDBERG, P.C.; THOLANDER, F.; THUNNISSEN, M. M.; SAMUELSSON, B.; HAEGGSTRÖM, J. Z. Leukotriene A4 hydrolase: selective abrogation of leukotriene B4 formation by mutation of aspartic acid 375. Proc Natl Acad Sci USA. 2002;99:4215-4220.

RUIZ-ORTEGA, M.; ESTEBAN, V.; EGIDO, J. The regulation of the inflammatory response through nuclear factor-kappab pathway by angiotensin IV extends the role of the renin angiotensin system in cardiovascular diseases. Trends Cardiovasc Med. 2007;17:19-25.

RYAN, A.; GODSON, C. Lipoxins: regulators of resolution. Curr Opin Pharmacol. 2010;10:166-172.

SALA, A.; BOLLA, M.; ZARINI, S.; MULLERr-PEDDINGHAUS, R.; FOLCO, G. Release of leukotriene A4 versus leukotriene B4 from human polymorphonuclear leukocytes. J Biol Chem. 1996;271:17944-17948.

SAMUELSSON, B.; DAHLÉN, S. E.; LINDGREN, .J. A.; ROUZER, C.A.; SERHAN C. N. Leukotrienes and lipoxins: structures, biosynthesis, and biological effects. Science. 1987;237:1171-1176.

SAMUELSSON, B.; FUNK, C. D. Enzymes Involved in the Biosynthesis of Leukotriene B4. J Biol Chem.1989;264:19469-19472.

SCOTT, D.L.; WOLFE, F.; HUIZINGA, T. W. J. Rheumatoid arthritis. Lancet. 2010;376:1094-1108.

SNELGROVE, R. J.; JACKSON, P. L.; HARDISON, M. T.; NOERAGER, B. D.; KINLOCH, A.; GAGGAR, A.; SHASTRY, S.; ROWE, S. M.; SHIM, Y. M.; USSELL, T.; BLALOCK, J. E. A Critical Role for LT-A4-H in Limiting Chronic Pulmonary Neutrophilic Inflammation. Science. 2010;330:70-74. 
STRIETHOLT, S.; MAURER, B.; PETERS, M. A.; PAP, T.; GAY, S. Epigenetic modifications in rheumatoid arthritis. Arthritis Res Ther. 2008;10:219.

STUART, J. M.; WATSON, W. C.; KANG, A. H. Collagen autoimmunity and arthritis. FASEB J. 1988;2:2950-2956.

STUART, J. M.; TOWNES, A. S.; KANG, A. H. Collagen autoimmune arthritis. Annu Rev Immunol. 1984;2:199-218.

TAKAMOTO, M.; YANO, T.; SHINTANI, T.; HIRAKU, S. A highly sensitive and selective method for the determination of Leukotriene B4 in human plasma by negative ion chemical ionization/gas chromatography/tandem mass spectrometry. J Pharm Biomedical Analysis. 1995; $13: 1465-1472$.

TRENTHAM, D.E.; TOWNES, A. S.; KANG, A. H. Autoimmunity to type II collagen an experimental model of arthritis. J Exp Med. 1977;146:857-868.

TU, G.; XU, W.; HUANG, H.; LI, S. Progress in the Development of Matrix Metalloproteinase Inhibitors. Current Medicinal Chemistry. 2008;15:1388-1395.

WERZ, O. 5-lipoxygenase: cellular biology and molecular pharmacology. Curr Drug Targets Inflamm Allergy. 2002;1:23-44.

WESTMAN, E.; LUNDBERG, K.; ERLANDSSON HARRIS, H. Arthritogenicity of collagen type II is increased by chlorination. Clin Exp Immunol. 2006;145:339-345.

WEYAND, C.M.; GORONZY, J.J. HLA polymorphisms and T cells in rheumatoid arthritis. Int Rev Immunology. 1999;18:37-59.

XU, S.; LU, H.; LIN, J.; CHEN, Z.; JIANG, D. Regulation of TNFa and IL1b in rheumatoid arthritis synovial fibroblasts by leukotriene B4. Rheumatol Int. 2010;30:1183-1189.

XUE, M.; MARCH, L.; SAMBROOK, P. N.; JACKSON, C. J. Differential Regulation of Matrix Metalloproteinase 2 and Matrix Metalloproteinase 9 by Activated Protein C: Relevance to Inflammation in Rheumatoid Arthritis. Arthritis \& Rheumatism. 2007;56(9):2864-2874.

YAMASAKI, S. C.; MURARI-DO-NASCIMENTO, S.; SILVEIRA, P. F. Neutral aminopeptidase and dipeptidyl peptidase IV in the development of collagen II-induced arthritis. Regul Pept. 2012;173:47-54.

YOKOMIZO, T.; IZUMI, T.; SHIMIZU, T. Leukotriene B4: metabolism and signal transduction. Arch Biochem Biophys. 2001;385:231-41.

ZAITSU, M.; HAMASAKI, Y.; MATSUO, M.; KUKITA, A.; TSUJI, K.; MIYAZAKI, M.; HAYASAKI, R.; MURO, E.; YAMAMOTO, S.; KOBAYASHI, I.; ICHIMARU, T.; KOHASHI, O.; MIYAZAKI, S. New induction of leukotriene A (4) hydrolase by interleukin4 and interleukin-13 in human polymorphonuclear leukocytes. Blood. 2000;96:601-609. 
ZAMBOTTI-VILLELA, L.; YAMASAKI, S. C.; VILLARROEL, J. S.; ALPONTI, R. F.; SILVEIRA, P. F. Aspartyl, arginyl and alanyl aminopeptidase activities in the hippocampus and hypothalamus of streptozotocin-induced diabetic rats. Brain Res. 2007;1170:112-118. 
11. ANEXO

Parte desta dissertação foi publicada em 13 de fevereiro de 2011 em 'Regulatory Peptides', artigo em anexo: MENDES, M. T.; MURARI-DO-NASCIMENTO, S.; TORRIGO, I. R.; ALPONTI, R. F.; YAMASAKI, S. C; SILVEIRA, P. F. Basic aminopeptidase activity is an emerging biomarker in collagen-induced rheumatoid arthritis. 2011;167:215-221. 


\title{
Basic aminopeptidase activity is an emerging biomarker in collagen-induced rheumatoid arthritis
}

\author{
Mariana Trivilin Mendes ${ }^{\mathrm{a}, \mathrm{b}}$, Stephanie Murari-do-Nascimento ${ }^{\mathrm{a}}$, Isis Rossetti Torrigo ${ }^{\mathrm{a}}$, \\ Rafaela Fadoni Alponti ${ }^{\text {, }}$, Simone Cristina Yamasaki ${ }^{a}$, Paulo Flavio Silveira ${ }^{a, *}$ \\ a Laboratory of Pharmacology, Instituto Butantan, Av. Vital Brasil, 1500, 05503-900 São Paulo, SP, Brazil \\ b Department of Physiology, Instituto de Biociências, Universidade de São Paulo, 05508-900 São Paulo, SP, Brazil
}

\section{A R T I C L E I N F O}

\section{Article history:}

Received 28 November 2010

Received in revised form 18 January 2011

Accepted 8 February 2011

Available online 13 February 2011

\section{Keywords:}

Aminopeptidase

Rat model

Inflammatory arthritis

Rheumatoid arthritis

Biomarker

\begin{abstract}
A B S T R A C T
The objective of this study was to investigate the catalytic activity of basic aminopeptidase (APB) and its association with periarticular edema and circulating tumor necrosis factor (TNF)-alpha and type II collagen (CII) antibodies (AACII) in a rat model of rheumatoid arthritis (RA) induced by CII (CIA). Edema does not occur in part of CII-treated, even when AACII is higher than in control. TNF-alpha is detectable only in edematous CII-treated. APB in synovial membrane is predominantly a membrane-bound activity also present in soluble form and with higher activity in edematous than in non-edematous CII-treated or control. Synovial fluid and blood plasma have lower APB in non-edematous than in edematous CII-treated or control. In peripheral blood mononuclear cells (PBMCs) the highest levels of APB are found in soluble form in control and in membranebound form in non-edematous CII-treated. CII treatment distinguishes two categories of rats: one with arthritic edema, high AACII, detectable TNF-alpha, high soluble and membrane-bound APB in synovial membrane and low APB in the soluble fraction of PBMCs, and another without edema and with high AACII, undetectable TNF-alpha, low APB in the synovial fluid and blood plasma and high APB in the membranebound fraction of PBMCs. Data suggest that APB and CIA are strongly related.
\end{abstract}

(C) 2011 Elsevier B.V. All rights reserved.

\section{Introduction}

Rheumatoid arthritis (RA) is an inflammatory, chronic, systemic and autoimmune disease [1,2] of unknown etiology [1-4] that affects about $1 \%$ of the world's population $[1,2,5]$. It is associated with increased mortality and significant comorbidities and other factors that can specifically affect a patient's quality of life [6,7]. The prominent characteristic of RA is a symmetrical peripheral polyarthritis with bone erosions, mainly of cartilage, and resultant deformity and joint destruction [8]. This process is associated with inflammatory hyperplasia of the synovial membrane, also known as pannus [9], and pathological neovascularization, which occur after the infiltration of inflammatory cells into the synovial membranes [10], as well as an immune response against cartilage components, among them the type II collagen (CII) has been thought to be the most usual [8]. Tumor necrosis factor (TNF)-alpha has also been found in high concentrations in the serum and synovial fluid of RA patients $[1,10]$.

Abbreviations: AACII, antibody anti-type II collagen; Ang, angiotensin; APB, basic aminopeptidase; BSA, bovine serum albumin; CII, type II collagen; CIA, collageninduced arthritis; LDH, lactate dehydrogenase; LTA4, leukotriene-A4; LTA4H, leukotriene A4-hydrolase; MF, membrane-bound fraction; NADH, nicotinamide adenine dinucleotide, reduced form; PBMCs, peripheral blood mononuclear cells; PGP, Pro-Gly-Pro; RA, rheumatoid arthritis; SF, soluble fraction.

* Corresponding author. Tel.: + 55117067 9058; fax: + 55113726 7222/2061.

E-mail address: pefesil@butantan.gov.br (P.F. Silveira).
The genetic predisposition linked to human leukocyte antigen system has been estimated to contribute with about $50 \%$ or less for the development of disease [11]. Thus, several epigenetic factors appear to be involved in the onset of RA, such as DNA methylation, alternative splicing, micro RNAs and histone modifications [11]. Moreover, factors such as infections, smoking, pregnancy, sex hormones and others may lead to autoimmunity [4]. CII is considered the primary antigen in RA, since it is the main constituent of cartilage [2] and because antibodies anti-CII (AACII) have been detected in synovial fluid [5,12], cartilage and B cells present in the synovial membrane of arthritic patients [12]. Furthermore, manifestations of RA have close similarity with those of the experimental model of CII-induced arthritis (CIA), that are: synovitis, progressive pannus formation, marginal erosion of bone and cartilage destruction $[5,12,13]$. The transfer of AACII is also able to induce RA, because these antibodies bind to normal cartilage and activate the complement system [5]. In the CIA model, symptoms of RA begin about 21 days after the injection of CII [13]. According to Stuart et al. [9], the initial lesion observed in this experimental model of RA is fibrin deposition in the synovial membrane 5 days after immunization. On the 12th day there is an intense deposition of fibrin and tissue hyperplasia. On the 19th day the infiltration of mononuclear and polymorphonuclear cells begins. Inflammation occurs so rapidly that the destruction of cartilage and the marginal erosion of the bone occur in a few days [9]. 
Regarding the evidences that altered matrix metalloproteinase and other proteins implicated in matrix degradation, cell activation, inflammation and bone collagen degradation products accompany early rheumatoid and osteoarthritis development and can precede the canonical diagnostic detection by several years [14,15], as well as that CD13, an aminopeptidase type enzyme, was histologically expressed strongly in RA synovial tissue lining cells [16], it can be hypothesized that changes of other aminopeptidase hydrolytic activities, such as the basic aminopeptidase (APB) activity, could be important in RA, mainly because APB activity was reported to be increased in the soluble fraction of elicited macrophages [17] and because kallidin [18], leukotriene(LT)-A4 [19,20] and angiotensin (Ang) III [21], three of the known natural substrates susceptible to hydrolysis by isozymes with APB activity, have recognized actions in regulating angiogenesis [22] and inflammation [23].

To prospect new markers and contribute to elucidate the etiology of RA, this study aims to assess changes in the APB activity of blood plasma, synovial fluid and soluble (SF) and solubilized membranebound (MF) fractions from the synovial membrane of the knee and from peripheral blood mononuclear cells (PBMCs), associating this enzyme activity with hind paw edema and with the AACII titer in blood plasma and TNF-alpha levels in blood serum of control and CIItreated rats.

\section{Materials and methods}

\subsection{Animals, treatments and samples}

Adult male Wistar rats, weighing $150-160 \mathrm{~g}$, provided by the Animal Facility of the Instituto Butantan, were maintained in polyethylene cages (inside length $\times$ width $\times$ height $=56 \times 35 \times 19 \mathrm{~cm}$ ) with food and tap water ad libitum, in a container with controlled temperature of $25^{\circ} \mathrm{C}$, relative humidity of $65.3 \pm 0.9 \%$ and $12 \mathrm{~h}: 12 \mathrm{~h}$ photoperiod light:dark (lights on at 6:00 am). The animals and research protocols used in this study are in agreement with the COBEA (Brazilian College of Animal Experimentation) and were approved by the Ethics Committee of the Instituto Butantan (682/09).

The animals were anesthetized with a solution of ketamine (Ketamine, Syntec, Cotia, São Paulo, Brazil) (3.75\%) and xylazine (Calmiun, Agener Union, Planalto Paulista, São Paulo, Brazil) (0.5\%) at a dose of $0.2 \mathrm{~mL} / 100 \mathrm{~g}$ body weight, via intraperitoneal, and then subjected to induction of arthritis by administration of CII from chicken (Sigma, St. Louis, MO, USA) dissolved in $0.01 \mathrm{M}$ acetic acid and emulsified in an equal volume of Freund's incomplete adjuvant (Sigma, St. Louis, MO, USA) (prepared at $4{ }^{\circ} \mathrm{C}$ just before use), via a single intradermal dose of $0.4 \mathrm{mg} / 0.2 \mathrm{~mL} /$ animal, into the proximal one-third of the tail (induced animals), or with $0.9 \%$ saline at the same scheme of administration (sham induction). On day 41 after treatment, the animals were anesthetized using the same scheme specified above and the thickness of the hind paws were measured in order to evaluate edema. Based on this measurement the following experimental groups were formed: Control (all animals submitted to sham induction); Arthritic (induced animals with hind paw thickness $>7 \mathrm{~mm}$ ); Resistant (induced animals with hind paw thickness similar to control). Thus, blood was withdrawn from the left ventricle with heparinized and not heparinized syringes in order to obtain plasma and serum, respectively. Heparinized blood was centrifuged (at $200 \times \mathrm{g}$ for $10 \mathrm{~min}$ at room temperature) to separate plasma (supernatant) from the pellet containing PBMCs and other blood cells. The non-heparinized blood was left at room temperature for $10 \mathrm{~min}$ and then centrifuged under the same conditions to obtain the serum. The synovial fluid and synovial membrane were subsequently removed from both knees of each animal. The withdrawal of synovial fluid and synovial membrane was performed as follows: $200 \mu \mathrm{L}$ of $0.9 \% \mathrm{NaCl}$ was injected intraarticularly into each knee and aspirated with a syringe and, after such washing, the synovial membrane was excised together with the connective tissue of the joint capsule.

\subsection{Separation of PBMCS}

According to the method of Maldonado and Curi [24] with modifications as follow: the pellet resulting from the obtainment of blood plasma was reconstituted to the original volume with $0.9 \%$ $\mathrm{NaCl}$ and then carefully layered on equal volume of Percoll $(\rho=1.077 \mathrm{mg} / \mathrm{mL})$ (GE-Healthcare) and subsequently centrifuged ( $200 \times \mathrm{g}$ for $20 \mathrm{~min}$ at room temperature). The layer containing the PBMCs was then removed from the tube and washed twice with $0.9 \%$ $\mathrm{NaCl}(1: 3 \mathrm{v} / \mathrm{v}$ diluted blood cells) and centrifuged again at the same conditions to discard the supernatant.

\subsection{Cell counting and viability}

PBMCs were resuspended in $0.5 \mathrm{~mL}$ of $0.9 \% \mathrm{NaCl}$. The total number of PBMCs was assessed in $20 \mu \mathrm{L}$ aliquots of this suspension diluted with Turk's fluid (1:20,v/v). The cell viability was assessed using $40 \mu \mathrm{L}$ aliquots of this suspension diluted in equal volume of Trypan. Cell counting was performed in a Neubauer chamber under optical microscopy.

\subsection{Evaluation of the canonical signs of $R A$}

\subsubsection{Paw edema}

Hind paw swelling was quantified by macroscopic measurement of the dorsal-plantar thickness of the hind paws in the region of the metatarsus with a paquimeter (Mitutoyo, Aurora, IL, USA). Both paws were measured and the average thickness was calculated for each animal.

\subsubsection{Molecular markers}

AACII was measured in blood plasma and TNF-alpha was measured in blood serum with Enzyme-Linked ImmunoSorbent Assay (ELISA) kits purchased from Chondrex (Redmond, WA, USA) and Biosource (Carlsbad, CA, USA), respectively, according to the manufacturer's recommendations.

\subsection{Obtaining SF and MF from the synovial membranes and PBMCS}

The synovial membranes from both knees of each animal were homogenized in $10 \mathrm{mM}$ Tris- $\mathrm{HCl}$ buffer, $\mathrm{pH} 7.4(0.1 \mathrm{~g}$ tissue $/ 3.0 \mathrm{~mL})$ for $3 \mathrm{~min}$ at 15,000 rpm (homogenizer Polytron-Aggregate, Kinematica, Lucerne, Switzerland). PBMCs, resuspended in $0.9 \% \mathrm{NaCl}$, were sonicated in $10 \mathrm{mM}$ Tris- $\mathrm{HCl}$, pH $7.4\left(3.0 \times 10^{6}\right.$ cells $\left./ \mathrm{mL}\right)$, for $10 \mathrm{~s}$ at an amplitude level of 40 microm at a constant frequency of $20 \mathrm{KHz}$. These samples were then ultracentrifuged at $100,000 \times \mathrm{g}$ for $35 \mathrm{~min}$ (ultracentrifuge Hitachi model CP60E). The resulting supernatants correspond to SF. The resulting pellets were washed twice with the same buffer and ultracentrifuged at $100,000 \times g$ for $35 \mathrm{~min}$, to assure the complete removal of SF. Subsequently, the pellet was homogenized for $3 \mathrm{~min}$ at $800 \mathrm{rpm}$ (homogenizer Tecnal TE 099, Tecnal, Piracicaba, SP, Brazil) with the same volume of the same buffer plus Triton X-100 (0.1\%) and ultracentrifuged again $(100,000 \times g$ for $35 \mathrm{~min}$ ). The resulting supernatants correspond to MF. All procedures were carried out at $4{ }^{\circ} \mathrm{C}$.

As a marker for the fractionation procedure, lactate dehydrogenase (LDH) activity was determined, photometrically, at $340 \mathrm{~nm}$, in SF and MF, as previously described [25]. Briefly, samples of $3 \mu \mathrm{L}$ of SF and MF, in triplicates, were incubated with $297 \mu \mathrm{L}$ of $100 \mathrm{mM}$ phosphate buffer, $\mathrm{pH}$ 7.4, containing $200 \mathrm{mM} \mathrm{NaCl}$ and $1.6 \mathrm{mM}$ sodium pyruvate solution (Sigma, St. Louis, MO, USA) and $0.2 \mathrm{mM}$ nicotinamide adenine dinucleotide, reduced form (NADH) disodium salt (Sigma, St. Louis, MO, USA). Two measurements of absorbance at $340 \mathrm{~nm}$ were performed: the first at 
zero time and the second after $10 \mathrm{~min}$ of incubation at $37^{\circ} \mathrm{C}$. Values of LDH activity ( $\mathrm{mM}$ oxidized NADH min $^{-1} \mathrm{mg}^{\text {protein }}{ }^{-1}$ ) were obtained by subtracting the values of the second from that of the first reading, and extrapolated by comparison with a standard curve of NADH.

\subsection{Total protein}

Total protein was measured photometrically (Bio-Tek Power Wave XR spectrophotometer, Bio-Tek, Winooski, VT, USA), at $630 \mathrm{~nm}$, in triplicates of $40 \mu \mathrm{L}$ of synovial fluid, plasma (diluted 500 -fold) and SF (diluted 10-fold) and MF (diluted 2-fold) from the synovial membrane and PBMCs by the method of Bradford [26], using a BioRad protein assay reagent (Hercules, CA, USA). Protein contents were extrapolated by comparison with standard curves of bovine serum albumin (BSA) in the same diluent.

\subsection{APB activity}

As previously described by Zambotti-Villela et al. [27], using $25 \mu \mathrm{L}$ individual samples of blood plasma (205 to $450 \mu \mathrm{g}$ protein), and synovial fluid (12 to $49 \mu \mathrm{g}$ protein) and the SF ( 2.8 to $20 \mu \mathrm{g}$ protein) and MF (2.6 to $15 \mu \mathrm{g}$ protein) from the synovial membrane, and $50 \mu \mathrm{L}$ and $100 \mu \mathrm{L}$ individual samples respectively of SF ( 22 to $72 \mu$ g protein) and MF (13 to $44 \mu \mathrm{g}$ protein) from PBMCs, on the basis of the amount of $\beta$-naphthylamine (Sigma, St. Louis, MO, USA) released as a result of the enzyme activity of samples incubated at $37^{\circ} \mathrm{C}$ for $30 \mathrm{~min}$ in $96-$ well flat bottom microplates (Corning Inc., NY, USA) with prewarmed substrate solution of $0.5 \mathrm{mM}$ L-arginine $\beta$-naphthylamide (Sigma, St. Louis, MO, USA) to a final volume of $300 \mu \mathrm{L}$ in $0.05 \mathrm{M}$ phosphate buffer, pH 6.5, with $150 \mathrm{mM} \mathrm{NaCl}, 0.02 \mathrm{mM}$ puromycin (Sigma, St. Louis, MO, USA) and $0.1 \mathrm{mg} \mathrm{BSA} / \mathrm{mL}$. $\beta$-Naphthylamine was estimated fluorometrically using the Bio-Tek FL600FA Microplate Fluorescence/ Absorbance Reader, at $460 / 40 \mathrm{~nm}$ emission wavelength and 360/ $40 \mathrm{~nm}$ excitation wavelength. The value of incubates at zero time (blank) was subtracted and the relative fluorescence was converted to picomoles of $\beta$-naphthylamine by comparison with a correspondent standard curve. APB activity was expressed as picomoles of hydrolyzed substrate $\min ^{-1} \mathrm{mg}$ protein ${ }^{-1}$.

\subsection{Data analysis}

Data are shown as mean \pm standard error of the mean (SEM) and were analyzed statistically using the GraphPad Instat ${ }^{\mathrm{TM}}$ software package. Regression analyses were performed to obtain standard curves of protein, NADH and $\beta$-naphthylamine. Student's $t$-test was performed to compare values of LDH between SF and MF. To compare values among the control, arthritic and resistant groups one-way analysis of variance (ANOVA) was performed, followed by Student-Newman-Keuls multiple comparisons test when differences were detected. In all the calculations a minimum critical level of $\mathrm{P}<0.05$ was set.

\section{Results}

\subsection{Induction of arthritis}

\subsubsection{Development of paw edema}

About $40 \%$ of the animals submitted to CII treatment did not develop paw swelling. Fig. 1 shows the swelling developed by animals "sensitive" to the treatment with CII relatively to the absence of swelling in control (sham induction) and animals "insensitive" to the treatment with CII.

\subsubsection{Molecular markers}

Table 1 shows that AACII titer in blood plasma of the CII-treated animals that developed or not the edema was higher than that of

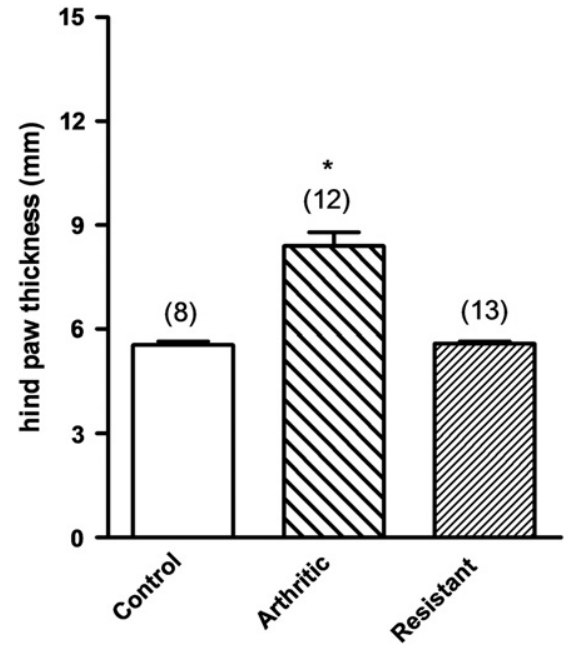

Fig. 1. Classification of experimental animals based on the formation of edema. Control group is sham induced, and arthritic and resistant groups are CII-treated. Values are means \pm SEM. Number of animals in parentheses. Analysis of variance ANOVA $(p<0.0001)$ with post-hoc Student-Newman-Keuls multiple comparisons test: ${ }^{*} \mathrm{p}<0.001$ vs control and vs resistant.

control. Table 1 also shows that TNF-alpha levels in blood serum did not differ between control and CII-treated animals without edema, but these levels were higher in blood serum of CII-treated animals with edema than in control.

\subsection{Efficiency of synovial membrane fractionation}

In all groups under study the LDH activity of the synovial membrane was detected only in the SF (mean \pm SEM, control group, $\mathrm{n}=8 ; 0.81 \pm 0.15, \mathrm{P}<0.0001$, unpaired, two-side Student's $t$ test); in the MF this activity was null (control group, $n=8$ ). Qualitatively similar results were obtained in the SF and MF from PBMCs of all groups (data not shown).

\subsection{APB activity}

Fig. 2 shows that APB activity is strongly expressed in the MF from the synovial membrane of all groups under study. APB activity in the SF and MF from the synovial membrane was higher in CIItreated animals with swollen paws (arthritic) than in control or CIItreated that did not develop paw swelling (resistant). Resistant and control animals had similar APB activity in the SF and MF from the

Table 1

Titer of antibodies anti-type II collagen (AAC-II) and levels of tumor necrosis factor (TNF)-alpha in sham induced (control), CIA-treated that developed hind paw edema (arthritic) and CIA-treated rats that did not develop hind paw edema (resistant).

\begin{tabular}{|c|c|c|}
\hline \multirow[t]{2}{*}{ Animals } & Blood plasma AAC-II & Blood serum TNF-alpha \\
\hline & $(\mu \mathrm{g} / \mathrm{mL})$ & $(\mathrm{pg} / \mathrm{mL})$ \\
\hline Control & $0.039 \pm 0.018(2)$ & $<4(2)$ \\
\hline Arthritic & $186 \pm 5.7(3)^{*}$ & $21.5 \pm 2.5(3)^{* *}$ \\
\hline Resistant & $191 \pm 1.5(3)^{*}$ & $<4(3)$ \\
\hline
\end{tabular}

Limit of detection of ELISA kit is $4 \mathrm{pg}$ TNF-alpha/mL.

Values are means \pm SEM.

Number of animals in parentheses.

Analysis of variance ANOVA $(\mathrm{p}<0.001)$ with post-hoc Student-Newman-Keuls multiple comparisons test.

$* \mathrm{p}<0.001$ vs control.

** $\mathrm{p}<0.001$ vs control and vs resistant. 


\section{SF of synovial membrane}
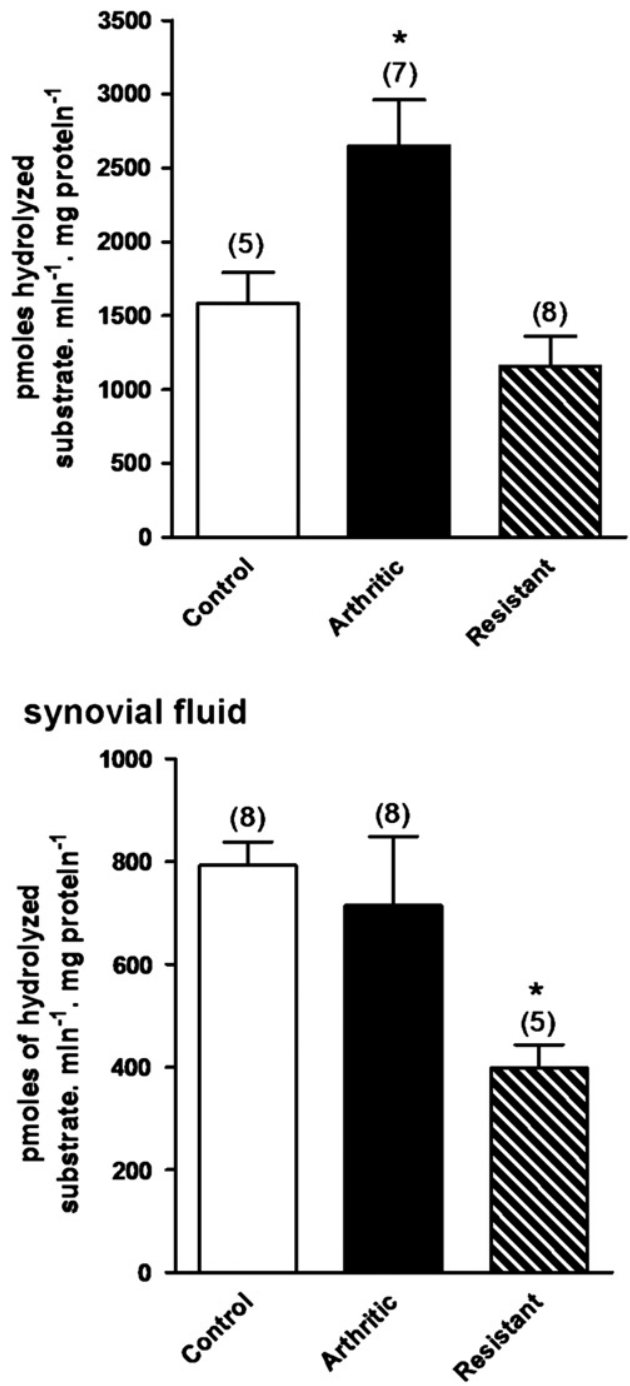

MF of synovial membrane

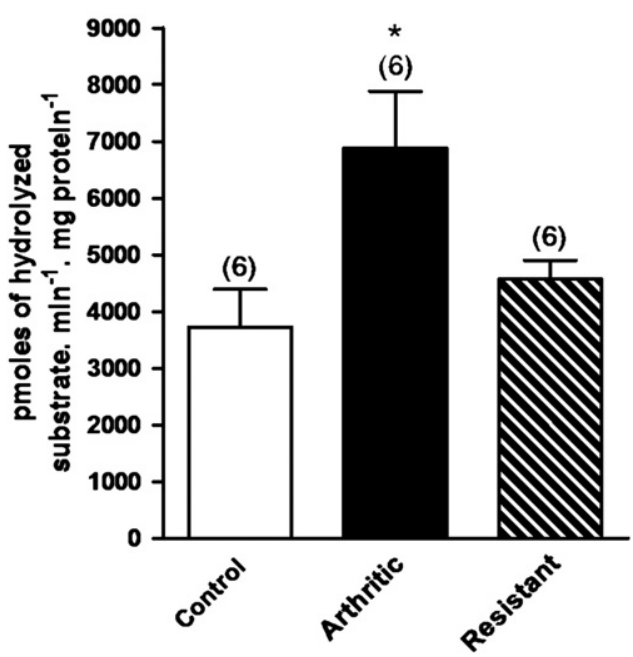

blood plasma

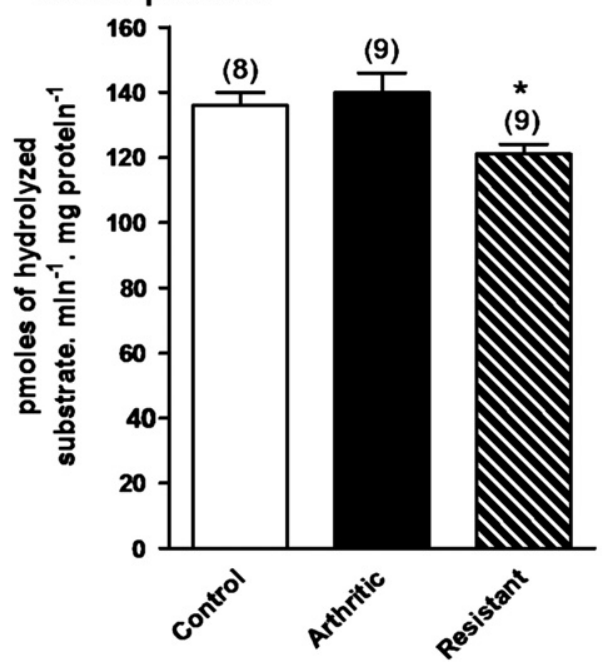

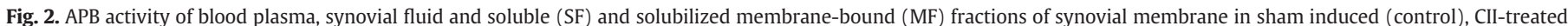

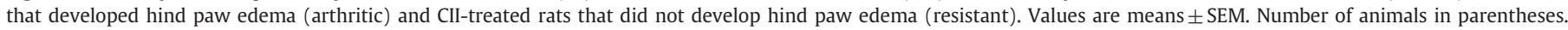

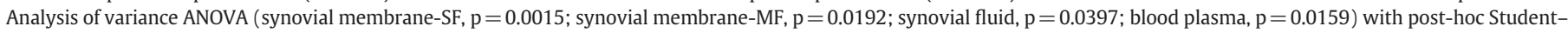
Newman-Keuls multiple comparisons test: ${ }^{*} \mathrm{p}<0.05$ vs other two groups.

synovial membrane. Fig. 2 also shows that APB activity in synovial fluid and blood plasma was lower in resistant than in control or arthritic animals, while arthritic animals and control animals had similar APB activity.

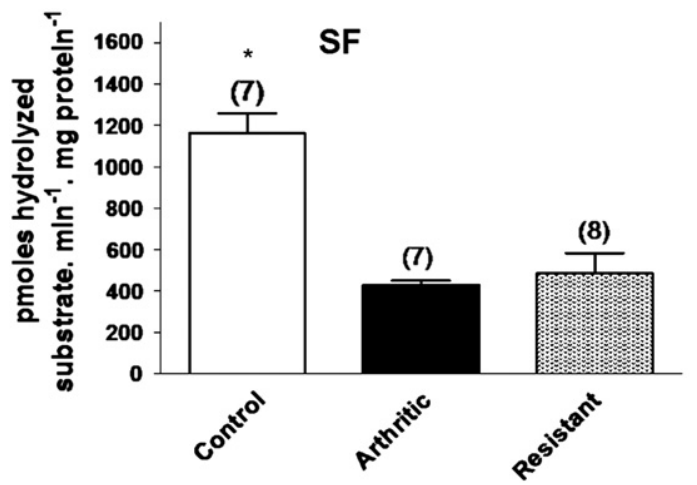

Fig. 3 shows that APB activity in the SF from PBMCs of control was higher than in arthritic or resistant animals. On the other hand, APB activity in the MF from PBMCs of resistant was higher than in control or arthritic animals.

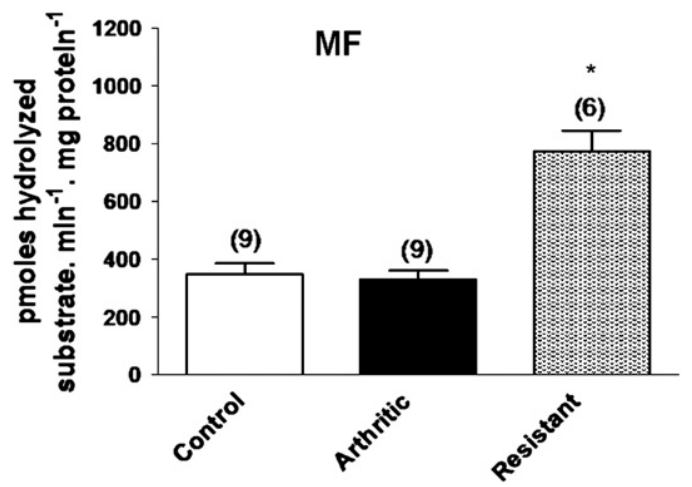

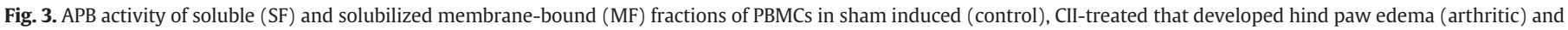

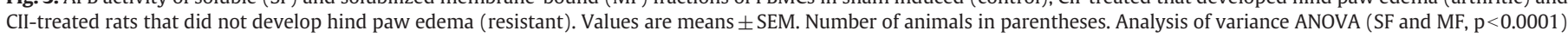
with post-hoc Student-Newman-Keuls multiple comparisons test: ${ }^{*} \mathrm{p}<0.001$ vs other two groups. 


\section{Discussion}

\subsection{Edema, AACII and TNF-alpha}

CIA in rats or mice is the most commonly used animal model to evaluate approved and pending therapies or to investigate the pathogenesis of RA. Based on the degree of hind paw swelling (edema) formed 41 days after the treatment with CII emulsified in Freund's incomplete adjuvant, the present study characterized the existence of CII-treated animals susceptible or resistant to the induction of RA. Edema of the paws is the main feature of RA induced by $\mathrm{CII}$ and is commonly used as a parameter for evaluating the presence of RA $[13,28]$. The incidence of RA (edema) was $44 \%$ and $100 \%$ in the methods of CIA used respectively by Trentham et al. [13] and Cuzzocrea et al. [28], while in the present study was about $60 \%$. TNF-alpha has been considered a major proinflammatory cytokine in RA $[1,10]$, and the differences detected here in TNF-alpha levels in serum among arthritic, resistant and control animals agree with this rule. Both CII-treated with edema and without edema showed a high AACII titer, which would be expected only in immunized animals with intense edematous response [29]. However, altered AACII titer occurs in several diseases [30] and as evidenced in the present study it could not be considered a differential parameter for RA. The present study describes for the first time that a considerable proportion of CIItreated animals with high AACII titer does not develop edema, a finding that reinforces the multifactorial feature of RA triggering and the hypothesis that CII, as a large molecule, contains different epitopes with different degrees of immunoreactivity for different antibodies, and these antibodies for CII could be pathogenic and nonpathogenic [30]. The distinction between these possible types of antibodies would have great impact on the diagnosis and treatment of RA.

\section{2. $A P B$ and the susceptibility and resistance to develop $R A$ in the CIA model}

Some factors can interfere with the successful onset of macroscopic signs of RA in CIA models, such as the denaturation of collagen during dissolution and differences in animal lineages used [31,32]. Obviously, the crucial question of medical interest is not related to the discrimination of exogenous factors that can determine the efficiency of the methods of induction, but the identification of possible endogenous determinants of resistance of certain animals to develop RA induced by these methods. On the other hand, as pointed out by Hegen et al. [33] the questions of which animal model is most predictive of therapeutic efficacy or has more pathophysiological features of human RA commonly arise in data evaluation, and obviously the study in several models can be more predictive than the data from either model alone. In this sense, the model used in the present study is very interesting because it showed that APB activity can be an attractive diagnostic tool for the determination of the outcome of RA, and that this catalytic activity can be also used to estimate the susceptibility to develop RA.

\subsection{Possible mechanisms generating the altered $A P B$ activity in the CIA model}

APB hydrolytic activity is known to be exhibited by the proteins EC 3.4.11.6 and leukotriene A4-hydrolase (LTA4H) (EC 3.3.2.6). The present study focuses only on APB catalytic activity without the aim to identify the protein(s) responsible for this activity. It is known that EC 3.4.11.6 preferentially hydrolyzes basic residues (arginine and lysine) of the N-terminal of several peptides [19,34], being widely distributed in various tissues as a monomeric protein with molecular weight of $72,300 \mathrm{kDa}[19,34]$, comprising 649 amino acid residues, showing 33\% identity and 48\% similarity with EC 3.3.2.6, and also exhibiting the catalytic activity of LTA4H $[19,20]$. In most cells studied, the protein EC
3.4.11.6 seems to be predominantly cytosolic and secreted, but it has also been found to be associated with the membrane $[18,19]$ and the Golgi apparatus, possibly transiting from the endoplasmic reticulum to the Golgi complex [18]. However, there is no description of transmembrane domains in its structure, and one hypothesis is that it interacts with a membrane receptor [19]. Intracellularly, the protein EC 3.4.11.6 could be involved in antigen processing, because it is present in the proteasome [35]. The peptides generated by proteasome degradation are incorporated into the endoplasmic reticulum where they bind to MHC II [35]. Moreover, many peptides in the endoplasmic reticulum undergo cleavage of $\mathrm{N}$-terminal residue [35] and the protein EC 3.4.11.6 could also act in that compartment, helping antigenic processing. On the other hand, the membraneassociated APB could act on extracellular angiogenic peptides such as kallidin [18] and Ang-III [21]. Pannus formation, in both RA and CIA, is angiogenesis-dependent and it has been increasingly recognized that peptides are part of a pathogenic mechanism that contributes to autoimmune inflammation in RA [36].

In the present study, the highest expression of APB activity was found in the membrane-bound fraction from the synovial membrane, and this activity was also present in the membrane-bound fraction from PBMCs after a successful fractionation of soluble and membranebound fractions from these samples, as demonstrated by LDH activity. Thus, the present study is the first one to analyze APB activity in these separate fractions from the synovial membrane and PBMCs. A question arised from this data is whether soluble APB activity in synovial fluid and blood plasma is derived from synovial membrane and/or PBMCs. For another aminopeptidase, the dipeptidyl peptidase IV, the mechanism of shedding from the cell surface to the plasma is thought to be caused by plasma enzymes [37]. This question and the pathophysiological significance of APB activity, not only in the membrane fraction but also in the soluble fraction from the synovial membrane, soluble and membrane fractions of PBMCs and in synovial fluid and blood plasma need further studies to be elucidated. For example, it is known that the APB activity of the protein EC 3.4.11.6 increases in the presence of physiological concentrations of chloride [34]. It is also known that changes in the levels of LTA4 and LTB4 (the product of the catalytic action of the proteins EC 3.3.2.6 and EC 3.4.11.6 on LTA4) generate changes in the APB activity of the protein EC 3.4.11.6 [15], but it is unclear whether there is a mutual interference of peptide and eicosanoid substrates in each of the catalytic activities of the protein EC 3.4.11.6. Moreover, both of the catalytic activities of the protein EC 3.3.2.6, that are epoxide hydrolase on LTA4 $[20,38,39]$ and peptide hydrolase on L-arginine $\beta$-naphthylamide and analogs [38-40], are inhibited by divalent cations and stimulated by monovalent anions, including chloride [34,40,41], as similarly occur with the protein EC 3.4.11.6 [34], thus complicating the distinction between these two proteins. Furthermore, the protein EC 3.3.2.6 appears to suffer suicidal inactivation when it is exposed to its lipid substrate LTA4 [34].

\subsection{Present significance of altered APB activity in the CIA model}

Although the present study does not help to distinguish whether one or both proteins are responsible for APB activity, in an important area of controversy it suggested that the balance of intracellular APB in PBMCs (activity in the soluble fraction of these cells) is crucial in the triggering of RA. Furthermore, the present study clearly demonstrated that the detection of increased levels of this catalytic activity in the soluble and membrane-bound fractions from the synovial membrane could help to the diagnosis of RA, while the detection of decreased levels of this catalytic activity in synovial fluid and blood plasma, as well as of increased levels in membrane-bound fractions from PBMCs is a feature of resistance to develop RA with potential prognostic implications. 


\subsection{Possible implications of altered $A P B$ activity in $R A$}

The role of polymorphisms in disease susceptibility is becoming increasingly relevant for the perspective of current medical practice [42]. Could a high stability of membrane-bound APB in the PBMCs and the consequent reduction of its release in body fluids be an individual protective factor against RA? It seems an interesting question to be further investigated. Recently, the neutrophil chemoattractant ProGly-Pro (PGP), a biomarker for chronic obstructive pulmonary disease, was identified as one of the physiological substrates of the aminopeptidase activity of LTA4H [43]. In acute neutrophil driven inflammation, PGP was degraded by aminopeptidase activity, which facilitated the resolution of inflammation, but in chronic obstructive pulmonary disease, the inhibition of this aminopeptidase activity could lead to the accumulation of PGP and neutrophils [43].

\subsection{Concluding remarks}

The treatment with CII emulsified in Freund's incomplete adjuvant leads the rats to develop arthritic edema, high AACII, detectable TNFalpha, high APB activity in the soluble and membrane-bound fractions from the synovial membrane and low APB in the soluble fraction of PBMCs or, on the other hand, absence of edema, high AACII, undetectable TNF-alpha, low APB in the synovial fluid and blood plasma and high APB in the membrane-bound fraction of PBMCs. Data suggest that APB represents potentially a new marker of diagnosis (in synovial membrane and soluble fraction from PBMCs) and/or prognosis (in synovial fluid, blood plasma and membrane-bound fraction from PBMCs) of RA. Given these data we believe that APB activity monitoring in RA patients at risk for or with existing joint pain and/or inflammation could be a cheap, simple and effective means to harness the clinical potential of this parameter for diagnosis and prognosis of RA. These data also suggest that the inhibition of APB activity in extracellular fluids such as synovial fluid and blood plasma needs to be investigated as a potential strategy for therapeutic intervention in RA.

\section{Acknowledgments}

This investigation was supported by Research Grant 09/17613-0 from FAPESP (Fundação de Amparo à Pesquisa do Estado de São Paulo, Brazil). P.F.S was a recipient of a Productivity Grant 301417/2008-3 from CNPq (Conselho Nacional de Desenvolvimento Científico e Tecnológico, Brazil). S.C.Y. was a recipient of a FAPESP fellowship. S.M-N was recipient of a CNPq fellowship. M.T.M. and R.F.A. were recipients of a CAPES (Coordenação de Aperfeiçoamento de Pessoal de Nível Superior, Brazil) fellowship.

\section{References}

[1] Doan T, Massarotti E. Rheumatoid arthritis: an overview of new and emerging therapies. J Clin Pharmacol 2005;45:751-62.

[2] Nakamura RM. Progress in the use of biochemical and biological markers for evaluation of rheumatoid arthritis. J Clin Lab Anal 2000;14:305-13.

[3] Brand DD, Kang AH, Rosloniec EF. Immunopathogenesis of collagen arthritis. Springer Semin Immunopathol 2003;25:3-18.

[4] Kobayashi S, Momohara S, Kamatani N, Okamoto H. Molecular aspects of rheumatoid arthritis: role of environmental factors. FEBS J 2008;275:4456-62.

[5] Hietala MA, Nandakumar KS, Persson L, Fahlén S, Holmdahl R, Pekna M. Complement activation by both classical and alternative pathways is critical for the effector phase of arthritis. Eur J Immunol 2004;34:1208-16.

[6] Giles JT, Malayeri AA, Fernandes V, Post W, Blumenthal RS, Bluemke D, VogelClaussen J, Szklo M, Petri M, Gelber AC, Brumback L, Lima J, Bathon JM. Left ventricular structure and function in patients with rheumatoid arthritis, as assessed by cardiac magnetic resonance imaging. Arthritis Rheum 2010;62: 940-51.

[7] Kobayashi H, Giles JT, Polak JF, Blumenthal RS, Leffell MS, Szklo M, Petri M, Gelber AC, Post W, Bathon JM. Increased prevalence of carotid artery atherosclerosis in rheumatoid arthritis is artery-specific. J Rheumatol 2010;37:730-9.
[8] Holmdahl R, Lorentzen JC, Lu S, Olofsson P, Wester L, Holmberg J, Pettersson U. Arthritis induced in rats with nonimmunogenic adjuvants as models for rheumatoid arthritis. Immunol Rev 2010;184:184-202.

[9] Stuart JM, Townes AS, Kang AH. Collagen autoimmune arthritis. Annu Rev Immunol 1984;2:199-218.

[10] Panayi GS. B cells: a fundamental role in the pathogenesis of rheumatoid arthritis? Rheumatology (Oxford) 2005;44:ii3-7.

[11] Strietholt S, Maurer B, Peters MA, Pap T, Gay S. Epigenetic modifications in rheumatoid arthritis. Arthritis Res Ther 2008;10:219-27.

[12] Cremer MA, Rosloniec EF, Kang AH. The cartilage collagens: a review of their structure, organization, and role in the pathogenesis of experimental arthritis in animals and in human rheumatic disease. J Mol Med 1998;76:275-88.

[13] Trentham DE, Towes AS, Kang AH. Autoimmunity to type II collagen an experimental model of arthritis. J Exp Med 1977;146:857-68.

[14] Ling SM, Patel DD, Garnero P, Zhan M, Vaduganathan M, Muller D, Taub D, Bathon JM, Hochberg M, Abernethy DR, Metter EJ, Ferrucci L. Serum protein signatures detect early radiographic osteoarthritis. Osteoarthritis Cartilage 2009;17:43-8.

[15] Mantle D, Falkous G, Walker D. Quantification of protease activities in synovial fluid from rheumatoid and osteoarthritis cases: comparison with antioxidant and free radical damage markers. Clin Chim Acta 1999;284:45-58.

[16] Koch AE, Burrows JC, Skoutelis A, Marder R, Domer PH, Anderson B, Leibovich SJ Monoclonal antibodies detect monocyte/macrophage activation and differentiation antigens and identify functionally distinct subpopulations of human rheumatoid synovial tissue macrophages. Am J Pathol 1991;138:165-73.

[17] Olivo RA, Teixeira CF, Silveira PF. Representative aminopeptidases and prolyl endopeptidase from murine macrophages: comparative activity levels in resident and elicited cells. Biochem Pharmacol 2005;69:1441-50.

[18] Balogh A, Cadel S, Foulon T, Picart R, Der Garabedian A, Rousselet A, Tougard C, Cohen P. Aminopeptidase B: a processing enzyme secreted and associated with the plasma membrane of rat pheochromocytoma (PC12) cells. J Cell Sci 1998;111: 161-9.

[19] Foulon T, Cadel S, Cohen P. Aminopeptidase B (EC 3.4.11.6). Int J Biochem Cell Biol 1999;31:747-50.

[20] Penning TD, Russell MA, Chen BB, Chen HY, Liang, Mahoney MW, Malecha JW, Miyashiro JM, Yu SS, Askonas LJ, Gierse JK, Harding EI, Highkin MK, Kachur JF, Kim SH, Villani-Price D, Pyla EY, Ghoreishi-Haack NS, Smith WG. Synthesis of potent leukotriene $\mathrm{A}(4)$ hydrolase inhibitors. Identification of 3-[methyl[3-[4-(phenylmethyl)phenoxy]propyl]amino]propanoic acid. J Med Chem 2002;45:3482-90.

[21] Ruiz-Ortega M, Esteban V, Egido J. The regulation of the inflammatory response through nuclear factor-kappab pathway by angiotensin IV extends the role of the renin angiotensin system in cardiovascular diseases. Trends Cardiovasc Med 2007; 17:19-252.

[22] Heffelfinger SC. The renin angiotensin system in the regulation of angiogenesis. Curr Pharm Des 2007;13:1215-29.

[23] Ryan A, Godson C. Lipoxins: regulators of resolution. Curr Opin Pharmaco 2010;10:166-72.

[24] Maldonado C, Curi R. Como Cultivar células. Rio de Janeiro: Guanabara Koogan; 2005.

[25] Gasparello-Clemente E, Casis L, Varona A, Gil J, Irazusta J, Silveira PF. Aminopeptidases in visceral organs during alterations in body fluid volume and osmolality. Peptides 2003;24:1367-72.

[26] Bradford MM. A rapid and sensitive method for the quantitation of microgram quantities of protein utilizing the principle of protein-dye binding. Anal Biochem 1976;72:248-54.

[27] Zambotti-Villela L, Yamasaki SC, Villarroel JS, Alponti RF, Silveira PF. Aspartyl, arginyl and alanyl aminopeptidase activities in the hippocampus and hypothalamus of streptozotocin-induced diabetic rats. Brain Res 2007:1170:112-8.

[28] Cuzzocrea S, Mazzon E, diPaola R, Genovese T, Muià C, Caputi AP, Salvemini D. Synergistic interaction between methotrexate and a superoxide dismutase mimetic: pharmacologic and potential clinical significance. Arthritis Rheum 2005;52:3755-60.

[29] Harris HE, Liljeström M, Klareskog L. Characteristics of synovial fluid effusion in collagen-induced arthritis (CIA) in the DA rat; a comparison of histology and antibody reactivities in an experimental chronic arthritis model and rheumatoid arthritis (RA). Clin Exp Immunol 1997;107:480-4.

[30] Morgan K. What do anti-collagen antibodies mean? Ann Rheum Dis 1990;49: 62-5.

[31] Cremer M. Type II collagen-induced arthritis in rats. In: Diamond HS, Greenwald RA. Handbook of animal model for the rheumatic diseases. CRC Press; 1988. p. 17-27.

[32] Brand DD, Latham KA, Rosloniec EF. Collagen-induced arthritis. Nat Protoc 2007; 2: 1269-75.

[33] Hegen M, Keith Jr JC, Collins M, Nickerson-Nutter CL. Utility of animal models for identification of potential therapeutics for rheumatoid arthritis. Ann Rheum Dis 2007;67:1505-15.

[34] Haeggström JZ. Leukotriene $\mathrm{A}_{4}$ hydrolase. In: Rawlings ND, Barrett AJ, Woessner JF, editors. Handbook of proteolytic enzymes. Academic Press; 1998. p. 1022-5.

[35] Hattori A, Tsujimoto M. Processing of antigenic peptides by aminopeptidases. Biol Pharm Bull 2004;27:777-80.

[36] Dennehey C, van den Broek T, van Wijk F, Zhang X, Zieseniss P, Le T, Prakken BA, Cutter GC, Albani S. Epitope-specific immunotherapy of rheumatoid arthritis: clinical responsiveness occurs with immune deviation and relies on the expression of a cluster of molecules associated with T cell tolerance in a doubleblind, placebo-controlled, pilot phase II trial. Arthritis Rheum 2009;60:3207-16.

[37] Gorrell MD, Gysbers V, McCaughan GW. CD26: a multifunctional integral membrane and secreted protein of activated lymphocytes. Scand J Immunol 2001;54(3):249-64. 
[38] Haeggström JZ, Tholander F, Wetterholm A. Structure and catalytic mechanisms of leukotriene A4 hydrolase. Prostaglandins Other Lipid Mediat 2007;83:198-202.

[39] Murphy RC, Gijón MA. Biosynthesis and metabolism of leukotrienes. Biochem J 2007:405:379-95

[40] Liang AM, Claret E, Ouled-Diaf J, Jean A, Vogel D, Light DR, Jones SW, Guilford WJ, Parkinson JF, Snider RM. Development of a homogeneous time-resolved fluorescence leukotriene B4 assay for determining the activity of leukotriene A4 hydrolase. J Biomol Screen 2007;12:536-45.
[41] Rudberg PC, Tholander F, Thunnissen MM, Haeggström JZ. Leukotriene A4 hydrolase/aminopeptidase. Glutamate 271 is a catalytic residue with specific roles in two distinct enzyme mechanisms. J Biol Chem 2002;277:1398-404.

[42] Cronstein BN. A personal journey from the joint to the heart. Arthritis Res Ther 2010;12:134.

[43] Snelgrove RJ, Jackson PL, Hardison MT, Noerager BD, Kinloch A, Gaggar A, Shastry S, Rowe SM, Shim YM, Hussell T, Blalock JE. A critical role for LTA4H in limiting chronic pulmonary neutrophilic inflammation. Science 2010;330:90-4. 